\title{
GFD Modelling of Ventilation Optimization for Improving Mine Safety in Longwall working faces
}

\author{
Jianwei Cheng ${ }^{1, a, b, c} *$, Siyuan $\operatorname{Li}^{\mathrm{a}}$, Fuxi Zhang ${ }^{\mathrm{b}}$, Changchun Zhao ${ }^{\mathrm{b}}$, Shengqiang \\ Yang $^{\mathrm{a}}$, Apruna Ghosh ${ }^{\mathrm{c}}$ \\ ${ }^{a}$ Key Laboratory of Gas and Fire Control for Coal Mines, China University of Mining and \\ Technology,Xuzhou,Jiangsu,221116,China \\ ${ }^{b}$ Postdoctoral workstation, Yangquan Coal Mining Group, Co. Ltd.,Yangquan, Shanxi, 045000, China \\ ${ }^{c}$ Department of Metallurgical and Minerals Engineering, Western Australian School of Mines, Curtin \\ University, Kalgoorlie, WA 6430, Australia
}

\begin{abstract}
Mining coal seams with high coal gas content and coal spontaneous combustion (SponCom) risk is often a challenge for mining engineers. Control measures for maintaining the gas concentration under the regulation permissible limit (Generally 1\%) as well as reducing coal fire risks must be taken simultaneously in order to create safety production conditions. However, in reality, such measures either for gas or for fire problems are sometimes conflictive. For an example, the basic strategy of gas control in underground is to increase the ventilation airflow for sweeping the longwall working face and diluting the gas concentration, but it also results in leakage of an amount of air into the mine gob area sufficient to supportthe coal SponCom development process. Conversely, sealing or isolating mine gob areas can easily cause the gas accumulation which may increase the gas explosion risk. To conquer this dilemma situation, it is necessary to deeply understand the coupling relationship between the mine gases and coal SponCom controls. In this paper, based on a real case in an underground coal mine, a ventilation parameters optimization research is conducted by using the Computational Fluid Dynamics (CFD) simulation approach for solving the stated contradiction problems to derive the optimum solutions for both managing gas hazards and fire risks in the underground. In this study, the boundary conditions are fully considered in accordance with the reality. A list of important ventilation parameters including the air quantity supplied to the mine working face, the negative ventilation pressure in the roof roadway for gas
\end{abstract}

* Corresponding author. Jianwei Cheng. Tel.: +86-516-8359-0598

E-mail address: jchengwvu@gmail.com 
drainage and reasonable distributed airflow quantity in tailgate roadways, are investigated. The research findings balance the requirements both for gas control and fire-prevention. The proposed method could be applied to guide the mine design practices in improving safety.

Keywords: Ventilation; Coal Gas; Coal Spontaneous Combustion; Coupling Relationship

\section{Introduction}

With the modern mining technology widely applied nowadays, the characteristics of a coal mine have been greatly changed, the scale of gas emission in the underground coal mines also expands by tens or thousands of times compared to before. In addition to that, the residual coal pieces during mining due to the recovery ratio limit could intensify the risk of coal spontaneous combustion (SponCom)[1], especially in mine gob areas. Thus, it can be seen that the mine gas as well as coal fire could seriously threat the miners' safety and healthy $[2,3]$. In reality, the required measures for controlling gas over the permissible limit often conflict with those for preventing coal SponCom. Gas drainage (Removal of gas from the coal seam and surrounding strata either by underground mine ventilation system or by drilling gas extraction boreholes) is a fundamental way to reduce the gas outburst (A sudden and violent ejection of coal, gas and rock from a coal face or surrounding strata in an underground coal mine) and gas explosion in a highly gassy mine. The in-seam gas pressure and content in coal seam could be reduced with applying gas drainage technology. Thus, the gas dilatation energy (Expansion of the released gas from underground coal seam) in the coal seams is accordingly reduced to avoid outbursts. In addition, it can also lower the gas emission in the underground coal working face and reduce the required ventilation air quantity flowed into the mine and maintain a suitable production environment [4]. Currently, using the roof gas drainage roadway, designing specialized gas drainage tailgate roadway and increasing ventilation air are the three best approaches used for gas control purposes [5]. A common point of these measures is that they could take gas away from the coal working faces or gob areas. However, they would also create several air leakage paths, which provide sufficient oxygen to intensify the coal SponCom in gobs. The combustion of coal would further lead to the gas combustion or 
explosion risks, which not only impacts on the safety of gas drainage working, but also causes a huge disaster for mining practices. Conversely, measures to prevent coal SponCom or decrease air leak may hinder the efficiency of gas drainage in the gob. Hence, it often faces a dilemma decision for mine operators.

Lot of researches has been done for gas distribution in a mine gob. Australian researchers used commercial CFD software to conduct a series of numerical simulation studies to investigate working face ventilation patterns under different gas drainage boundary conditions [6-8]. Xu developed a methodology that combines tracer gas and CFD modeling to remotely analyze underground mine ventilation systems [9]. Karacan analyzes production performances of Gob Gas Ventholes (GGVs) drilled over a longwall panel which are used as a methane control measure for strata gas not to enter and inundate the ventilation system of a mine [10]. In China, Some researchers have made numerical simulation study on U-type and Y-type ventilation pattern for coal working face in the gob by using the FLUENT software based on the real permeability distributions which could better reflect the gas migration situation in the mining area[11]. Such works improve the understanding of ventilation characteristics in and around mine working faces. In terms of simulation experimental researches on the coal oxidation in the low-temperature condition, carbon monoxide (CO) and carbon dioxide $\left(\mathrm{CO}_{2}\right)$ emissions during a spontaneous heating event in a coal mine are important gases to monitor for detecting the spontaneous heating at an early stage has been noticed by researchers [12-14]. Scholars generally used artificial coal SponCom experiments to simulate the primitive conditions of coal to observe its oxidation process under different external conditions [15-19]. Some large-scale SponCom experiment devices or theoretical analysis are developed to study the coal SponCom $[20,21]$. The relationship between the ventilation air and coal SponCom has been greatly studied.

In China, the underground coal working face generally applies the "U-shape" retreat ventilation system which has advantages of simple structure; small and stable air leakage and effective management, but the disadvantage is that the gas may be accumulated at the upper corner of face to reach the regulation limits (1\%). On the other hand, the gas drainage has become one of the major gas control methods. However, because of the low permeability in most coal seams in 
China, it results in low gas drainage rates and poor gas drainage effects. Therefore, the "U-shape" retreat ventilation system could well deal with the gas control problems in China. Therefore, many coal mine operators have revised the working face ventilation pattern. A new series types, such as "Y" shape, "W" shape and "U+L" shape have been developed. These ventilation patterns could obtain excellent effects for gas control in mining a single gassy coal seam.

However, for mining multiple coal seams, mining a coal seam leads to the regional gas pressure relief in the overlying or underlying strata, so that the coal gas at the fracture zone could inundate mine gobs, which would further lead to gas concentration build-up in the tailgate roadway as well as coal working face. Hence, the roadway layout and ventilation pattern mentioned above obviously may fail to meet the requirements to control gas. Further, two new working face ventilation patterns, " $\mathrm{U}+\mathrm{L}+$ roof gas drainage roadway" and " $\mathrm{U}+\mathrm{I}+$ roof gas drainage roadway", are used to retain the desorbed gas by adjacent coal seams by using the "Roof gas drainage roadway" so as to reduce gas concentrations both in tailgate roadways and working faces, which can efficiently reduce the risk of gas over limit. With increasing the negative suction pressure of the roof roadway to increase the gas drainage efficiency, not only the coal gas desorbed from coal seams but also an amount of ventilation air from the mine working face are drawn in to the roof roadway, which also result in the possible air-leakage problems leading to widen the coal SponCom zone in the gob area as well as coal fire risk. Conversely, if the pressure is decreased, there is no doubt that the risk of coal SponCom zone can be mitigated, but it often causes the gas build-up in the tailgate roadways or coal faces to over limit. It is thus clear to see that balancing the measures of control gas and of coal SponCom risk is a complicated problem.

In this paper, a real fully-mechanized coal caving face in a mine located in northern part of China is taken as the research object and a series of numerical simulation studies are conducted for optimizing ventilation parameters (e.g: ventilation air quantity, negative suction pressures of tailgate roadway and roof roadway for gas drainage, etc.). The findings could provide an optimal range of these ventilation parameters to maintain gas concentration under control and also to avoid any coal SponCom risk in mine gobs. 


\section{Backgroud of Mine and Longwall Working Face}

The studied coal working face is a fully-mechanized top coal caving working face which is also the first mining face in this coal mine and the annual coal production of the mine is 900,000 tons / year. The gas content of this face is $35.04 \mathrm{~m}^{3} / \mathrm{t}$ and the gas emission rate is $104 \mathrm{~m}^{3} / \mathrm{min}$. The coal face uses the ventilation pattern of " $\mathrm{U}+\mathrm{I}+$ Roof gas drainage roadway" and the layout diagram of the coal face is shown as below.

\section{Figure 1 coal seams over coal working face}

Table 1 shows proximate analysis on the coal sample taken from the mined coal seam. The coal SponCom propensity is also listed.

Table 1: Coal proximate analysis and SponCom propensity

According to the coal sample temperature oxidation test results, the shortest SponCom period model for this coal seam is about 33 days.

\section{Numerical Simulation Modelling}

Based on the geometric dimension of the underground longwall working face, a corresponding numerical simulation physical model is established in computer. The specific parameters are:

$>$ the calculation region is a hexahedron with a length of $200 \mathrm{~m}$, width of $152 \mathrm{~m}$ and height of 70m;

$>$ the volume of the coal working face is $3 \mathrm{~m} \times 152 \mathrm{~m} \times 2 \mathrm{~m}$;

$>$ the volume of ventilation roadway is $20 \mathrm{~m} \times 4 \mathrm{~m} \times 2 \mathrm{~m}$;

$>$ the volume of tailgate roadway is $20 \mathrm{~m} \times 2 \mathrm{~m} \times 2 \mathrm{~m}$;

$>$ the horizontal distance and vertical distance from the tailgate roadway to the air-return roadway are $30 \mathrm{~m}$ and $9 \mathrm{~m}$, respectively, and extend $2 \mathrm{~m}$ into the gob;

the volume of roof gas drainage roadway is $70 \mathrm{~m} \times 2 \mathrm{~m} \times 2 \mathrm{~m}$;

$>$ the horizontal distance and vertical distance from the roof roadway to the air-return roadway are both $60 \mathrm{~m}$.

The numerical physical model of the coal working face and its meshing is shown as figure 2 .

Figure 2 Physical model of the coal face and its meshing 
Based on the geological condition and gas reservoir characteristics in the working face, the numerical simulation of gas source consists of three parts: (1) the first part is the residual coal in the mine gob of the No.15 coal seam, the thickness is $1.05 \mathrm{~m}$ and the initial gas content as $7.13 \mathrm{~m}^{3} / \mathrm{t}$; (2) the second part is the No.14, No.13, No.12 and No.11 coal seams between the coal face and the roof gas drainage roadway. The coal thickness of No.14 coal seam is $0.96 \mathrm{~m}$, coal thickness of No.13 coal seam as $0.21 \mathrm{~m}$, initial gas content for each of them is $17.79 \mathrm{~m}^{3} / \mathrm{t}$. Coal thickness of No.12 coal seam is $0.55 \mathrm{~m}$ while initial gas content as $14.75 \mathrm{~m}^{3} / \mathrm{t}$. Coal thickness of No.11 coal seam is $0.32 \mathrm{~m}$ and initial gas content is $15.64 \mathrm{~m}^{3} / \mathrm{t}$; (3) the third part is the coal seams above the roof gas drainage roadway. Due to the size of the model, this simulation study combines No. $8_{-1}$ and No. $8_{-2}$ and No.9 coal seam as one seam, and the combined coal thickness is set as $1.1 \mathrm{~m}$ and gas content is set as 25.0 $\mathrm{m}^{3} / \mathrm{t}$. Table 2 shows the ventilation parameters. A commercially available CFD software program, FLUENT from Ansys, Inc., was used in this study

\section{Table 2 Ventilation parameters of the working face}

The boundary conditions are set based on differetnt research targets:

- Boundary conditions to investagate varying ventilation air quantity flowed into the coal working face

In order to simulate the coupling relationship between gas and fire with the variable coal face ventilation air quantity, the boundary condition of inlet way is set as "velocity-inlet" with the oxygen mass concentration in intake air roadway as $23 \%$. The air-return roadway, tailgate roadway and roof roadway are set as "outflow". To study on the change of SponCom zones under different combinations of airflow and gob gas emission, the ventilation air quantity in the underground working face could be changed from $1100 \mathrm{~m}^{3} / \mathrm{min}$ to $2000 \mathrm{~m}^{3} / \mathrm{min}$. Thus, a reference point is set per $100 \mathrm{~m}^{3} / \mathrm{min}$ interval. Hence, there are totally 10 simulation scenarios which would be calculated. At this moment, the air distribution ratio of ventilation air of the air-return roadway to tailgate roadway is set as 6(air in return):4 (air in tailgate roadway). The gob is customized as a porous media.

- Boundary conditions under different negative pressure in roof roadway 
In order to simulate the coupling relationship between gas and fire with the variable negative pressure in the roof roadway, the boundary condition of inlet way is set as "pressure-inlet" with the oxygen mass concentration of inlet way is $23 \%$. The air return, tailgate and roof roadways are set as "pressure-out". To study effects of gas drainage under different negative pressure in roof roadway, the values of negative pressure are set to accord with the on-site. There are 4 simulation scenarios which are the pressure is set as $0 \mathrm{~Pa},-1000$ $\mathrm{Pa},-2000 \mathrm{~Pa}$ and $-3000 \mathrm{~Pa}$, respectively. The air distribution ratio of ventilation air of the air-return roadway to tailgate roadway is still set as 6 (air in return):4 (air in tailgate roadway). The gob is customized as a porous media.

- Boundary conditions under different negative pressure in tailgate roadway

In order to simulate the coupling relationship between gas and fire with the variable negative pressure of the tailgate roadway, for convenience reasons, the effect caused by the negative pressure in tailgate roadway is the same that of the air distribution ratio of the air-return way to tailgate roadway. The boundary condition of inlet way as "velocity-inlet" with the oxygen mass concentration of inlet way is set as $23 \%$ and that of air return roadway, tailgate roadway and roof roadway is as "outflow". To study the change of coal SponCom zones under different tailgate roadway negative pressure and gob gas emission, various air distribution ratio of ventilation air of the air-return roadway to tailgate roadway is considered. Based on field measurement results, there are 7 simulation scenarios under different ratios would be calculated.

\section{Simulation Reults and Disscussion}

\subsection{Effects of ventilation airflow on gob gas emission and coal SponCom in longwall working face}

4.1.1 Effects of ventilation airflow on gob gas emission

In order to study the influence of coal face ventilation air quantity on gas emission in the gob, a total of 10 different ventilation air quantity varying from $1100 \mathrm{~m}^{3} / \mathrm{min}$ to $2000 \mathrm{~m}^{3} / \mathrm{min}$ is made. Rresults are shown in table 3: 
Table 3 Simulation results

The fitting curve of the variation propensity of the gas parameters in the air return way, tailgate roadway and face upper corner as shown in figure 3,4 and 5 .

Figure 3 The fitting curve of the variation propensity of gas parameters in the air return way

Figure 4 The fitting curve of the variation propensity of gas parameters in the tailgate roadway

Figure 5 The fitting curve of the variation propensity of the gas parameters in the face upper corner

- From the influence of ventilation air quantity on the gas parameters of air return roadway shown in figure 3 , it can be seen that the pure gas content increases monotonously with the increase of ventilation air; but gas concentration in air return way is not the same. When the ventilation air quantity is $1800 \mathrm{~m}^{3} / \mathrm{min}$, gas concentration shows the minimum value, and then the gas concentration becomes increasing in direct proportion to the ventilation air quantity. By figure 3, it can be concluded that the gas concentration can be lowered through increasing ventilation air within a proper range; blindly increasing ventilation air sometimes makes counterproductive result which may increases gas concentration.

- From the influence of ventilation air on the gas parameters in the tailgate roadway shown in figure 4, it can be seen that both the gas concentration and pure gas content in the tailgate roadway decreases with increase of ventilation air. The gas concentration is reduced more greatly. The reason is that the major part gas source in the tailgate roadway is from gobs, when the gas emission in the gob keeps unchanged, the increased air leakage could dilute the gas flowing to the tailgate roadway.

- From the influence of ventilation air quantity on the gas concentration in the upper corner shown in figure 5 , it can be seen that its change trend is similar to the trend of gas concentration in the air-return roadway as shown in figure 3. When the ventilation air is $1800 \mathrm{~m}^{3} / \mathrm{min}$, the gas concentration reaches the minimum value.

- By regression analysis for simulation results, it can be obtained that there are two significant quadratic term functional relationships between ventilation airflow $\mathrm{Q}$ and $\mathrm{CH}_{4} \%$ in the air 
return roadway and $\mathrm{CH}_{4} \%$ is as shown in figures 3 and 5. It is reasonably determined that both the $\mathrm{CH}_{4} \%$ in air return roadway and upper corner could decrease to minimum when $\mathrm{Q}=1880$ $\mathrm{m}^{3} / \mathrm{min}$, which means it is the best ventilation airflow to control the coal gas.

4.1.2 Effects of ventilation aiflow on coal SponCom in gob

In order to study the influence of ventilation air quantity on the SponCom in mine gobs, simulation study was made on the SponCom zones following the pervious stated 10 scenarios. The ventilation airflow ranges from $1100 \mathrm{~m}^{3} / \mathrm{min}$ to $2000 \mathrm{~m}^{3} / \mathrm{min}$ and the reference point is set per 100 $\mathrm{m}^{3} / \mathrm{min}$. Simulation results are listed in table 4 .

\section{Table 4 Parameters of simulation results}

The fitting curve of the range of SponCom zones with the change of ventilation air is shown in figure 6;

Figure 6 Fitting curves of the range of SponCom zones with the change of ventilation air

\section{Figure 7 An example of possible SponCom zone ventilation airflow is $1300 \mathrm{~m}^{3} / \mathrm{min}$}

- As shown in figure 7 and table 4 , in the air intake side, air leakage flow is greatly impacted by the effect of inertia. Thus, the SponCom zone is closer to the deeper part of the gob; while in the air return side, the $\mathrm{U}+\mathrm{I}$ ventilation pattern makes air leakage flow subject to the "dragging" of both the air return way and the tailgate roadway, so that the width of the SponCom zone is stretched, which increases the risk of SponCom in and around the upper corner of face and the tailgate roadway.

- As shown in figure 6, by using U+I ventilation pattern, the possible SponCom zone does not significantly increase with the increase of ventilation air quantity in the air intake side and the middle part of the gob; while the length of the possible SponCom zone "L" logarithmically increases with the increase of ventilation air Q, namely:

$$
L=b_{0} \ln (Q)+b_{1}
$$

Where: $b_{0}$ and $b_{1}$ are regression coefficients, which are 29.62 and 43.55 ;

$\mathrm{Q}$ is ventilation airflow;

The possible SponCom zone L can be calculated as: 


$$
L=29.62 \ln (Q)+43.55
$$

The coefficient of determination $R^{2}=0.971>0.7$ which indicates this formula is reliable.

- The natural oxidation of the residual coal in the gob usually refers to the SponCom happens due to the coal mining time span over the shortest SponCom period. According to control requirements for coal SponCom, the maximum width limit of zone is:

$$
L_{\max }=v \cdot \tau
$$

Where: $v$ is average mining advance rate;

$\tau$ is the shortest SponCom period;

The average mining rate of longwall face is $v=3.0 m / d$ and the shortest SponCom period is $\tau=33 d$,thus $L_{\max }=3 \times 33=99 m$.

$\mathrm{L}_{\max }$ could be submitted in the formula (4) to derive the ventilation airflow $Q_{\max }=1679 \mathrm{~m}^{3} / \mathrm{min}$, which indicates that the maximum airflow could be delivered into the working face in order to avoid SponCom risk.

\subsubsection{Determination of the Safety Range of Ventilation Airflow Supply}

- According to the comprehensive statistical analysis on estimated gas content of working face and gas emission characteristics during mining, the total gas emission in the working face is about $104 \mathrm{~m}^{3} / \mathrm{min}$, which includes $24 \mathrm{~m}^{3} / \mathrm{min}$ from No. 15 coal seam, $80 \mathrm{~m}^{3} / \mathrm{min}$ from the adjacent coal seams. The gas drainage efficiency of roof roadway is $86 \%$ which indicates that $90 \mathrm{~m}^{3} / \mathrm{min}$ of gas emission is discharged. The remaining $15 \mathrm{~m}^{3} / \mathrm{min}$ is diluted and discharged by ventilation air. Hence, about $5 \mathrm{~m}^{3} / \mathrm{min}$ gas emission is diluted in the air-return roadway and $5 \mathrm{~m}^{3} / \mathrm{min}$ gas emission is diluted in the tailgate roadway. Hence the minimum ventilation airflow can be calculated by:

$$
\begin{aligned}
Q_{\min } & =Q_{A}+Q_{B}=Q_{A}^{C H 4} / 1 \% \times \mathrm{K}_{A}^{C H 4} \times \mathrm{K}_{A}^{\text {spare }}+Q_{B}^{C H 4} / 2.5 \% \times \mathrm{K}_{B}^{C H 4} \times \mathrm{K}_{B}^{\text {spare }} \\
& =5 / 1 \% \times 1.3 \times 1.4+10 / 2.5 \% \times 1.2 \times 1.2 \\
& =910+576=1486\left(\mathrm{~m}^{3} / \mathrm{min}\right)
\end{aligned}
$$

Where: 
$Q_{\min }$ is minimum working face ventilation airflow, $\mathrm{m}^{3} / \mathrm{min}$;

$Q_{A}$ is the air airflow at air-return roadway, $\mathrm{m}^{3} / \mathrm{min}$;

$Q_{B}$ is the air airflow at tail roadway, $\mathrm{m}^{3} / \mathrm{min}$;

$Q_{A}^{C H 4}$ is gas emission at \#15 coal seam, $\mathrm{m}^{3} / \mathrm{min}$;

$Q_{B}^{C H 4}$ is gas emission from adjacent coal seams, $\mathrm{m}^{3} / \mathrm{min}$;

$\mathrm{K}_{A}^{C H 4}$ and $\mathrm{K}_{B}^{C H 4}$ are coal face gas emission differential coefficients which are equal to 1.3 and 1.2.

$\mathrm{K}_{A}^{\text {spare }}$ and $\mathrm{K}_{B}^{\text {spare }}$ are coal face ventilation air spare coefficients which are equal to 1.4 and 1.2.

- The coal face ventilation airflow must meet the requirement of $Q_{\min }<Q_{\text {actual }}<Q_{\max }$ in order to control the gas under regulation limit and SponCom risk in mine gob. In other words, if the ventilation airflow is $<Q_{\min }$, gas concentration will be over $1 \%$, and if it is $>Q_{\max }$, possible coal SponCom will occur. In this simulation study, the permissible ventilation airflow at coal working face is ranging from $1486 \mathrm{~m}^{3} / \mathrm{min}$ to $1679 \mathrm{~m}^{3} / \mathrm{min}$. However, the ventilation airflow in the working face currently used by mine operators is about $1800 \mathrm{~m}^{3} / \mathrm{min}$ for controlling the gas. Hence, it could be concluded that the SponCom risk threats the mining safety. For this reason, the ventilation airflow should be reduced down to $1700 \mathrm{~m}^{3} / \mathrm{min}$.

\subsection{Effects of negative suction pressure in roof roadway on gob gas emission and coal} SponCom in gob

4.2.1 Effect of the negative suction pressure on gob gas emission

In order to study the influence of the negative pressure on gas drainage, simulation works are made when the negative pressure is set at $0 \mathrm{~Pa},-1000 \mathrm{~Pa},-2000 \mathrm{~Pa}$ and $-3000 \mathrm{~Pa}$ and the simulation results are shown in table 5. 


\section{Table 5 Parameters of simulation results}

From table 5, it can be seen that:

- With the increase of the negative pressure, the roof roadway gas drainage flow increases significantly, while that in air-return way and tailgate roadway decreases slightly. The flow of roof gas drainage is doubled at pressure of $-2000 \mathrm{~Pa}$ compared to that of $-1000 \mathrm{~Pa}$, while the gas flows in the air-return roadway and in the tailgate roadway only decrease $1.2 \%$ and $0.3 \%$, respectively. This is because of the high gas concentration in the roof gas drainage roadway. Only a small flow quantity increase will greatly improve the pure gas flowrate. The situations of the air return way and the tailgate roadway are just opposite. Hence, the changes of gas in ventilation air can be ignored.

- With increase of the negative pressure, the gas concentration decreases slightly from $96.50 \%$ at $-1000 \mathrm{~Pa}$ to $87.17 \%$ at $-3000 \mathrm{~Pa}$ with a decreasing rate of $9.67 \%$. When the gas drainage flow rate increases, the gas emission in the gob and nearby coal seams also increases but the scale is relatively low, thus the change trend of gas drainage rate is decreasing in general. The gas concentration in the air return way almost keeps unchanged since the major source of ventilation air methane is from the coal working face. On the other hand, the gas concentration at the tailgate roadway decreases substantially from $3.43 \%$ at $-1000 \mathrm{~Pa}$ to $2.31 \%$ at $-3000 \mathrm{~Pa}$ with a decreasing rate of $32.65 \%$. The reason is that only a small part of gas comes from coal working face and most comes from the mine gob. When the roof roadway for gas drainage extracts a great deal of gas from the gob, the task of gas discharged by the tailgate roadway is greatly relieved. When the pressure of roadway is 0 (the roof roadway for gas drainage stops working), the gas concentration in the tailgate roadway can reach to $5.69 \%$, which goes far beyond 2.5\% (the upper limit of gas concentration stated in "Chinese Regulation for Coal Mine Safety Production" - hereinafter referred to as "Regulation"). When the negative pressure is set $-3000 \mathrm{~Pa}$, the gas concentration in the tailgate roadway is $2.31 \%$, which conforms to the requirements of "Regulation". 
- With increase of the negative pressure, gas concentration in roof roadway slightly decreases, but the pure gas content increases greatly and drainage efficiency increases significantly from $64.03 \%$ at $-1000 \mathrm{~Pa}$ to $87.75 \%$ at $-3000 \mathrm{~Pa}$.

Figures 8 and 9 are the color chart of the gas concentration and the vector diagram of airflow in the gob.

\section{Figure 8 Cloud chart of the gas concentration}

\section{Figure 9 The vector diagram of airflow in the gob}

\subsubsection{Effect of Negative Pressure on coal SponCom zones in gob}

In order to study the influence of the negative pressure on coal SponCom zones in the gob, simulation study is done when the negative pressure is set at $0 \mathrm{~Pa},-1000 \mathrm{~Pa},-2000 \mathrm{~Pa}$ and $-3000 \mathrm{~Pa}$. The simulation results are shown in table 6 .

\section{Table 6 Parameters of simulation results}

- As shown in table 6 and figure 10 and 11, under the condition of roof roadway, the possible SponCom zone in the air inlet side may go much deeper in the gob. The upper boundary of the possible SponCom zone goes about $20 \mathrm{~cm}$ deeper at $-3000 \mathrm{~Pa}$ than that at $0 \mathrm{~Pa}$. However, the possible SponCom zone in the air return roadway may be much closer to the working face. The lower boundary of the possible SponCom zone at $-3000 \mathrm{~Pa}$ goes about $18 \mathrm{~cm}$ further than that at 0Pa. The width of possible SponCom zone at central gob keeps almost unchanged due to the resultant effects of "pulled" by the roof gas drainage roadway and "dragged" by tailgate roadway.

\section{Figure10 Possible SponCom zones (Pressure is 0Pa)}

Figure11 Possible SponCom zone (Pressure is -3000Pa)

- With respect to the width of possible SponCom zone, the width of possible SponCom zone is broadened by $18 \mathrm{~m}$ as the negative pressure is changed from $-3000 \mathrm{~Pa}$ to $0 \mathrm{~Pa}$; the central part is broadened by $11 \mathrm{~m}$; and the air return side is narrowed by $20 \mathrm{~m}$. Assume that the average mining advance rate of working face is $v=3 m / d$, the extended time of 6.0 days and 3.7 days in air intake side and the gob central part makes the coal staying in the calefactive oxidation zone, while the air-return way decreased by 6.7 days. The increasing width of the possible SponCom 
zone in the air-intake side is obviously unfavorable to SponCom preventions; although the width of possible SponCom zone in air-return side is narrowed, the oxygen concentration in the coal face is high. Besides, under the " $\mathrm{U}+\mathrm{L}+$ Roof roadway" ventilation pattern, the airflow velocity in the air-return side is very low which may cause coal oxidation and thermal storage of float coal. Hence, to a certain extent, SponCom risk is more likely to occur in the air-return side gob.

\subsubsection{Determination of Safety Range of negative Pressure}

From table 5 , it is clearly revealed that the negative pressure of the roof roadway for gas drainage has a significant impact on decreasing the gas concentration in tailgate roadway. Based on the pervious simulation data, simulation study is made on the pressure at $-500 \mathrm{~Pa},-1500 \mathrm{~Pa}$ and $-2500 \mathrm{~Pa}$, respectively, to investigate the gas concentration in tailgate roadway and the results are shown in table 7.

\section{Table 7 Parameters of simulation results}

\section{Figure 12 Effect of roof negative pressure to the $\mathrm{CH}_{4} \%$ in tail roadway}

- By using the regression equation listed in figure 12 , it can be concluded that in order to control the gas concentration below $2.5 \%$ (required by Regulation), the lowest negative pressure of the tailgate roadway is $-2360 \mathrm{~Pa}$, thus the safety range of the negative pressure of roof roadway for gas drainage is pressure over $2360 \mathrm{~Pa}$.

- It can be seen from table 6 that if the ventilation air in coal face keeps unchanged, increasing negative pressure from $0 \mathrm{~Pa}$ to $-3000 \mathrm{~Pa}$ can just broaden the SponCom zone by $20 \mathrm{~m}$. According to the capability of the pump used in coal mine, the maximum adjustable range of negative pressure is up to $500 \mathrm{~Pa}$, thus the changing width of possible SponCom zone is up to $4 \mathrm{~m}$. Therefore, it can be concluded that the influence of the negative pressure of the roof roadway for gas drainage on SponCom prevention can be ignored in practical situation.

- In consideration of two aspects mentioned above, it can be concluded that controlling gas concentration within regulations at the cost of holding small SponCom risk is acceptable. The adjustable range of negative pressure is controlled within 500Pa. Thus, adjustable range of negative pressure at roof roadway is $2360 \mathrm{~Pa}<$ Pressure $<2860 \mathrm{~Pa}$. 


\subsection{Effects of Negative Pressure in Tailgate Roadway on Gas Emission and Coal SponCom in Gob}

In order to study the influence of the negative pressure of the tailgate roadway on gas emission and SponCom in the gob, the ventilation airflow keeps unchanged. The negative pressure of the tailgate roadway is adjusted to study the changes of gas concentration in the air-return roadway and the tailgate roadway as well as the SponCom zones in the gob. In order to directly reflect the range ability of the negative pressure of the tailgate roadway, the air distribution ratio of ventilation air of the air-return roadway to tailgate roadway is introduced. The total of ventilation air referring to the real mine case is set at $1800 \mathrm{~m}^{3} / \mathrm{min}$.

\subsubsection{Effect of Negative Pressure on Gob Gas Emission}

Simulation of the change trend of gas concentration at mine gob is shown in figure 13.

Figure 13 Change trend of gas concentration in mine gob

The simulation study is made on the condition that the ventilation air quantity in the tailgate roadway is set at $600 \mathrm{~m}^{3} / \mathrm{min}, 700 \mathrm{~m}^{3} / \mathrm{min}, 800 \mathrm{~m}^{3} / \mathrm{min}, 900 \mathrm{~m}^{3} / \mathrm{min}$ and $1000 \mathrm{~m}^{3} / \mathrm{min}$. It is discovered that the range ability of gas concentration in air-return roadway and in tailgate roadway is greater when the ventilation air is ranging between $600 \mathrm{~m}^{3} / \mathrm{min}$ and $800 \mathrm{~m}^{3} / \mathrm{min}$, thus other two more simulation scenarios are added when the ventilation air quantities in the tailgate roadway are $650 \mathrm{~m}^{3} / \mathrm{min}$ and $750 \mathrm{~m}^{3} / \mathrm{min}$. The changes of the gas concentration in roadways with the change of negative pressure is shown in table 8 .

Table 8 The change of the concentration of ventilation air methane with the change of negative pressure of the tailgate roadway

- From table 8, it can be concluded that with increase of the negative pressure of the tailgate roadway, the air distribution ratio of ventilation air of the air-return roadway to tailgate roadway decreases. The gas concentration in air-return roadway greatly reduces at first. Although the ventilation air quantity in tailgate roadway just increases by $100 \mathrm{~m}^{3} / \mathrm{min}$ from 600 $\mathrm{m}^{3} / \mathrm{min}$ to $700 \mathrm{~m}^{3} / \mathrm{min}$. The gas concentration decreases from $0.88 \%$ to $0.51 \%$. $0.88 \%$ is very close to the gas regulation limit (1\%), while $0.51 \%$ is relatively very safe. It could say that the 
slight $100 \mathrm{~m}^{3} / \mathrm{min}$ adjustment of ventilation air brings qualitative change to the gas safety in working face. However, continuous increasing the negative pressure in the tailgate roadway does not evidently change the gas concentration in air-return roadway any more, but changes slowly instead.

- The gas concentration in the upper corner of the air return roadway shares the same change with that of the air-return roadway. When the ventilation air quantity in the tailgate roadway is $600 \mathrm{~m}^{3} / \mathrm{min}$, the gas concentration in upper corner of the air return roadway is $1.60 \%$, which has seriously over the regulation (1\%). When increases the negative pressure of the tailgate roadway to increase the ventilation air quantity to $700 \mathrm{~m}^{3} / \mathrm{min}$, the gas concentration drops to $0.62 \%$. It is visible that increasing the negative pressure of the tail roadway is an effective way to control gas in the upper corner.

- With the increase of the negative pressure of the tailgate roadway, the gas concentration in the tailgate roadway increases at first and then decreases, and the increase section goes far beyond the decrease section. In the increase section, increasing ventilation air by just $100 \mathrm{~m}^{3} / \mathrm{min}$ may lead to the increase of gas concentration in the tailgate roadway from $0.98 \%$ to $1.53 \%$. In the decrease section, the increase of ventilation air by $300 \mathrm{~m}^{3} / \mathrm{min}$ just leads to the decrease of gas concentration from $1.53 \%$ to $1.25 \%$, a decrease of $0.09 \%$ per $100 \mathrm{~m}^{3} / \mathrm{min}$.

- From table 8 , it can be seen that, at the stage of increasing negative pressure at tailgate roadway, the gas concentrations in the air return roadway, the tail roadway and the face upper corner are all decreasing. For gas control in a coal mine, this is an ideal state. However, it should be noted that as the ventilation air exceeds $750 \mathrm{~m}^{3} / \mathrm{min}$, gas concentrations at the air return roadway and upper corner almost keep unchanged and the concentration at the tailgate roadway decreases slowly. Therefore, based on economic considerations, there is no necessary to increase the negative pressure of tailgate roadway too high. The reasonable air distribution of the tailgate is about $700 \sim 800 \mathrm{~m}^{3} / \mathrm{min}$. At this time, the return air quantity is $1020 \sim 1100 \mathrm{~m}^{3} / \mathrm{min}$. 


\subsubsection{Effect of Negative Pressure on Coal SponCom Zones in Gob}

The simulation study is made on the possible SponCom zone in the gob on the condition that the ventilation air quantity in tailgate roadway is ranging from $600 \mathrm{~m}^{3} / \mathrm{min}$ to $1100 \mathrm{~m}^{3} / \mathrm{min}$ and the reference point is set at $600 \mathrm{~m}^{3} / \mathrm{min}, 700 \mathrm{~m}^{3} / \mathrm{min}, 800 \mathrm{~m}^{3} / \mathrm{min}, 900 \mathrm{~m}^{3} / \mathrm{min}, 1000 \mathrm{~m}^{3} / \mathrm{min}$ and $1100 \mathrm{~m}^{3} / \mathrm{min}$. The simulation results are shown in table 9 . Figure 14 is the scatter diagram of the possible SponCom zone in air-return side.

\section{Table 9 Parameters of simulation results}

\section{Figure 14 Scatter diagram of the possible SponCom zone in air return side}

- By observing table 9, it can be concluded that as the ventilation air increased from $600 \mathrm{~m}^{3} / \mathrm{min}$ to $800 \mathrm{~m}^{3} / \mathrm{min}$, the possible SponCom zone in the gob does not change evidently. Zone in the air inlet side and in the central gob remained unchanged and only that in the air-return side increases slightly. When the ventilation air quantity is continued to increase. The SponCom zone in air-intake side and in central gob part may be narrowed down, but that in the air return side is increased significantly. With increasing the negative pressure and ventilation air of the tailgate roadway, the air leaked from coal face to the gob increases, so does the possible SponCom zone. The SponCom zone in the air return side verifies this rule. However, at the air intake side, a great deal of leaked air which should flow to the gob by inertia is pulled back by the negative pressure of the tailgate roadway, thus the area of the possible SponCom zones of the air intake side would not increase but decrease instead. However, this rule is not universal. This is because the distance from the tailgate roadway to the air-intake roadway in this example is just $120 \mathrm{~m}$ and the air leakage of the intake side is seriously subjected to the negative pressure of tailgate roadway. For a large-scale coal working face, the three SponCom zones in the entire gob may increase in direct proportion to the negative pressure.

- In this example, particular attention is paid to the range of SponCom zone" in air-return roadway and tailgate roadway. From figure 14, it can be clearly seen that the width of possible SponCom zones in these two roadways is large and increases with increase of ventilation air quantity. Hence, special fire management should be taken to control possible fire in air return and tailgate roadways. 
- With increase of the negative pressure of tailgate roadway, the range of possible SponCom zones, regardless of the air intake side or the air return side, will be closer to the coal face, which is unfavorable to the SponCom prevention.

- The spontaneous combustion risk in air-return side is enhanced with increasing air quantity in the tail roadway. Therefore, the reasonable range of the negative pressure in tailgate roadway should be determined on the basis of spontaneous combustion zone in return-air side.

4.3.3 Determination of the Reasonable Range of the Airflow Distribution in Tailgate Roadway

In considerations of gas control, the optimal range of air distribution in the tailgate is about $700 \sim 800 \mathrm{~m}^{3} / \mathrm{min}$, while, for SponCom prevention, the increase of the negative pressure of the tailgate roadway may lead to the increase of air leakage into mine gob, which further increases the SponCom risk. However, at the same time, the air leakage may be drawn by the same negative pressure of the tailgate roadway, which may offset the inertia of the air leakage towards mine gob, thus the air distribution range of the SponCom in the gob does not change greatly. Therefore, the optimal range of air distribution in tailgate can be $700 \sim 800 \mathrm{~m}^{3} / \mathrm{min}$, and the corresponding air return quantity is $1100 \sim 1000 \mathrm{~m}^{3} / \mathrm{min}$.

\section{Conclusions}

Control measures for maintaining the gas concentration within the permissible limit as well as reducing coal fire risks are mostly conflictive. However, they are often considered simultaneously in order to implement underground safety production. Hence, it is required that mining engineers carefully conduct these measures and balance their effects. In this work, the CFD numerical simulation as a tool is used to investigate the complicated relationship among various ventilation parameters and their effects on gas control and coal SponCom risk. Good ventilation parameters could make underground mining as safe as possible. Therefore, the key research point for guiding the ventilation management of the longwall working face is summarized as: 
- Increasing the ventilation air could reduce the gas concentrations in the air-return and tailgate roadways as well as the longwall face upper corner. But it may enhance the SponCom risk in mine gob. Based on comprehensive analysis, the recommaded ventilation air for the studied mine is $1486 \mathrm{~m}^{3} / \mathrm{min} \sim 1679 \mathrm{~m}^{3} / \mathrm{min}$.

- Increasing the negative pressure of roof gas drainage roadway can reduce the gas concentrations in the roof and tailgate roadways and rarely affects on concentration in the air-return roadway. In addition, it also enhances the SponCom risk in mine gob, but the influence is limited in size and extent.

- The gas concentration of the air-return roadway and the face upper corner is reduced with increasing the ventilation airflow in the tailgate roadway, but that of the tailgate roadway increases at first and then decreases. The SponCom risk in mine gob is intensified. The case study mine's current total in-take ventilation airflow is $1800 \mathrm{~m}^{3} / \mathrm{min}$. About $700 \sim 800 \mathrm{~m}^{3} / \mathrm{min}$ ventilation airflow should be split in tailgate roadway while the ventilation airflow in the air-return roadway is $1100 \sim 1000 \mathrm{~m}^{3} / \mathrm{min}$.

\section{Acknowledgements}

This work is financially supported by grants from the Fundamental Research Funds for Central Universities (Grant No. 2013QNA01; 2015XKMS007), the National Science Foundation of China (Grant No.51304203), the Natural Science Foundation of Jiangsu Province of China for Youths (Grant No. BK20130191) and Specialized Research Fund for the Doctoral Program of Higher Education (Grant No. 20130095120001); the Program for Changjiang Scholars and Innovative Research Team in University (IRT13098) and Priority Academic Program Development of Jiangsu Higher Education Institutions; the authors are grateful for these supports. 


\section{References}

[1] S.A. C., L.C. P. Inhibition of Spontaneous combustion of coal, Report of investigation-Unites States. Bureau of mines, Pittsburgh, PA, USA, 1988.

[2] R.V.K. Singh. Spontaneous Heating and Fire in Coal Mines. Procedia Engineering (2013), 78-90.

[3] J. Lu, J. Liu. Present Status and Development of Mine Disaster Prevention and Control Technology. Coal Science and Technology. 12 (2006), 18-23.

[4] A.P. Sasmito, E. Birgersson, H.C. Ly, A.S. Mujumdar. Some approaches to improve ventilation system in underground coal mines environment - A computational fluid dynamic study. TUNN UNDERGR SP TECH (2013), 82-95.

[5] X. Li. Chinese Coal Mine Safety Cyclopedia. China Coal Industry Publishing House, Beijing, 1998.

[6] T.X. Ren, J.S. Edwards, R.R. Jozefowicz. CFD modeling of methane flow around longwall coal faces. Proceedings of the 6th International Mine Ventilation Congress (1997), 17-22.

[7] S. Shi, E. Al. Computer simulation study on goaf air leakage and distribution. Journal of China Coal Society. 23 (1998), 67-70.

[8] M. Wendt, R. Balusu. CFD modeling of longwall goaf gas flow dynamics. Coal and Safety (2002), 17-34.

[9] G. Xu, E.C. Jong, K.D. Luxbacher, S.A. Ragab, M.E. Karmis. Remote characterization of ventilation systems using tracer gas and CFD in an underground mine. SAFETY SCI (2015), 140-149.

[10] C.Ö. Karacan. Analysis of gob gas venthole production performances for strata gas control in longwall mining . INT J ROCK MECH MIN (2015), 9-18.

[11] Q. Xu, S. Yang, B. Yu. Study on the seepage law of coal-rock fragments in goaf. 2009 Asia Pacific Coalbed Methane Symposium and 2009 China Coalbed Methane Symposium2009.

[12] L. Yuan, A.C. Smith. $\mathrm{CO}$ and $\mathrm{CO} 2$ emissions from spontaneous heating of coal under different ventilation rates . INT J COAL GEOL. 88 (2011), 24-30.

[13] D. Lopez. Effect of low temperature oxidation of coal on hydrogen-transfer capability. FUEL. 77 (1998), 1623-1628.

[14] L. Yuan, A.C. Smith. Numerical study on effects of coal properties on spontaneous heating in longwall goaf areas. FUEL. 87 (2008), 3409-3419.

[15] L. Yuan, A.C. Smith. Experimental study on $\mathrm{CO}$ and $\mathrm{CO} 2$ emissions from spontaneous heating of coals at varying temperatures and O2 concentrations. J LOSS PREVENT PROC. 26 (2013), 1321-1327.

[16] T.X. Ren, J.S. Edwards. Adiabatic oxidation study on the propensity of pulverized coals to spontaneous combustion. FUEL. 78 (1999), 1611-1620.

[17] K. Chen, Y. Xia, C. Dai. Study on coal oxidation experimental regularity. Coal science and technology. 38 (2000), 1-4.

[18] K.K. Feng. Spontaneous combustion of Canadian coals. CIM Bulletin. 78 (1985), 71-75.

[19] B. Taraba, Z. Michalec, V. Michalcová, T. Blejchař, M. Bojko, M. Kozubková. CFD simulations of the effect of wind on the spontaneous heating of coal stockpiles . FUEL (2014), 107-112.

[20] Y. Qi. Study on Combustion Charecteristics of Coal Absorbing Flow-state Oxygen and Application in Mine Fire Prediction. Safety in Coal Mines (1994), 1-6.

[21] K. Hooman, U. Maas. Theoretical analysis of coal stockpile self-heating . FIRE SAFETY J (2014), 107-112. 
Table 1: Coal proximate analysis and sponcom propensity

\begin{tabular}{|c|c|c|c|c|c|c|}
\hline \multicolumn{2}{|c|}{$\begin{array}{c}\text { Proximate analysis } \\
(\%)\end{array}$} & $\begin{array}{c}\text { Total sulfur } \\
\text { St,ad (\%) }\end{array}$ & $\begin{array}{c}\text { True relative } \\
\text { density dTRD }\end{array}$ & $\begin{array}{c}\text { Oxygen } \\
\text { absorbed } \\
\text { Vdcm } 3 / g(d r y \\
\text { coal) }\end{array}$ & $\begin{array}{c}\text { Sponcom } \\
\text { propensity }\end{array}$ \\
\cline { 1 - 2 } Mad & Ad & Vdaf & & 1.85 & 0.71 & Easy \\
\hline
\end{tabular}


Table 2 Ventilation parameters of fully-mechanized top coal caving face

\begin{tabular}{cccc}
\hline Parameter & $\begin{array}{r}\text { Geometry size } \\
x \times y \times z(m \times m \times m)\end{array}$ & $\begin{array}{c}\text { Gas emission } \\
\left(\mathrm{m}^{3} / \mathrm{min}\right)\end{array}$ & Porosity \\
Site & $2 \times 152 \times 2$ & & 0.9 \\
name & $3 \times 152 \times 2$ & 13.8 & 0.40 \\
Working face & $40 \times 150 \times 70$ & 10.2 & 0.15 \\
Shield & $160 \times 150 \times 70$ & 54 & 0.10 \\
Gob near face & $20 \times 4 \times 2$ & $/$ & $/$ \\
Vob away face & $20 \times 2 \times 2$ & $/$ & $/$ \\
roadilation & $70 \times 2 \times 2$ & $/$ & $/$ \\
Tail roadway & & & \\
Roof roadway & & & \\
\hline
\end{tabular}


Table 3 Parameters of simulation results

\begin{tabular}{cccccc}
\hline \multirow{2}{*}{$\begin{array}{c}\text { Airflowate } \\
/ \mathrm{m}^{3} / \mathrm{min}\end{array}$} & \multicolumn{2}{c}{$\begin{array}{c}\text { Gas drainage parameters in } \\
\text { return }\end{array}$} & $\begin{array}{c}\text { Gas drainage parameters in } \\
\text { tailgate }\end{array}$ & $\begin{array}{c}\text { Face upper corner gas } \\
\text { concentration } / \%\end{array}$ \\
\cline { 2 - 4 } & $\begin{array}{c}\text { Gas } \\
\text { concentration } / \%\end{array}$ & $\begin{array}{c}\text { Gas flowrate } \\
/ \mathrm{m}^{3} / \mathrm{min}\end{array}$ & $\begin{array}{c}\text { Gas } \\
\text { concentration } / \%\end{array}$ & $\begin{array}{c}\text { Gas flowate } \\
/ \mathrm{m}^{3} / \mathrm{min}\end{array}$ & \\
\hline & & & & & 0.73 \\
1100 & 0.68 & 4.49 & 2.69 & 11.84 & 0.68 \\
1200 & 0.63 & 4.54 & 2.45 & 11.76 & 0.64 \\
1300 & 0.60 & 4.68 & 2.24 & 11.65 & 0.61 \\
1400 & 0.57 & 4.79 & 2.07 & 11.59 & 0.57 \\
1600 & 0.55 & 4.95 & 1.91 & 11.46 & 0.54 \\
1700 & 0.52 & 4.99 & 1.77 & 11.33 & 0.52 \\
1800 & 0.51 & 5.20 & 1.65 & 11.22 & 0.49 \\
1900 & 0.49 & 5.29 & 1.54 & 11.09 & 0.64 \\
2000 & 0.51 & 5.81 & 1.39 & 10.56 & 0.73 \\
\hline
\end{tabular}


Table 4 Parameters of simulation results

\begin{tabular}{cccc}
\hline $\begin{array}{c}\text { Ventilation } \\
\text { airflow in air-intake } \\
\text { roadway } \\
/ \mathrm{m}^{3} / \mathrm{min}\end{array}$ & $\begin{array}{c}\text { Width of possible } \\
\text { SponCom zone in the } \\
\text { air-intake side } / \mathrm{m}\end{array}$ & $\begin{array}{c}\text { Width of possible } \\
\text { SponCom zone in the } \\
\text { central gob/m }\end{array}$ & $\begin{array}{c}\text { Width of possible } \\
\text { SponCom zone in the } \\
\text { air-return side } / \mathrm{m}\end{array}$ \\
\hline 1100 & 28 & 32 & 50 \\
1200 & 30 & 38 & 61 \\
1300 & 32 & 41 & 72 \\
1400 & 32 & 42 & 82 \\
1500 & 33 & 42 & 89 \\
1600 & 34 & 43 & 94 \\
1700 & 36 & 43 & 101 \\
1800 & 36 & 43 & 113 \\
1900 & 38 & 44 & 116 \\
2000 & 38 & 44 & \\
\hline
\end{tabular}


Table 5 Parameters of simulation results

\begin{tabular}{|c|c|c|c|c|c|c|c|c|c|c|}
\hline \multirow[b]{2}{*}{$\begin{array}{l}\text { Negati } \\
\text { ve } \\
\text { pressu } \\
\text { re in } \\
\text { roof } \\
\text { roadw } \\
\text { ay } / \mathrm{Pa}\end{array}$} & \multicolumn{3}{|c|}{ High level entry } & \multicolumn{3}{|c|}{ Air-return roadway } & \multicolumn{3}{|c|}{ Tailgate roadway } & \multirow[b]{2}{*}{$\begin{array}{l}\text { Draina } \\
\text { ge } \\
\text { efficien } \\
\text { cy } \\
1 \%\end{array}$} \\
\hline & $\begin{array}{c}\text { Mixe } \\
\text { d } \\
\text { flow } \\
\mathrm{m}^{3} / \mathrm{m} \\
\text { in }\end{array}$ & $\begin{array}{c}\text { Gas } \\
\text { concentrat } \\
\text { ion } 1 \%\end{array}$ & $\begin{array}{c}\text { Gas } \\
\text { draina } \\
\text { ge } \\
\text { purity } \\
/ \mathrm{m}^{3} / \mathrm{m} \\
\text { in }\end{array}$ & $\begin{array}{c}\text { Mixe } \\
\text { d } \\
\text { flow } \\
/ \mathrm{m}^{3} / \mathrm{m} \\
\text { in }\end{array}$ & $\begin{array}{c}\text { Gas } \\
\text { concentrat } \\
\text { ion } / \%\end{array}$ & $\begin{array}{l}\text { Gas } \\
\text { draina } \\
\text { ge } \\
\text { purity } \\
/ \mathrm{m}^{3} / \mathrm{m} \\
\text { in }\end{array}$ & $\begin{array}{c}\text { Mixe } \\
\text { d } \\
\text { flow } \\
/ \mathrm{m}^{3} / \mathrm{m} \\
\text { in }\end{array}$ & $\begin{array}{c}\text { Gas } \\
\text { concentrat } \\
\text { ion } 1 \%\end{array}$ & $\begin{array}{c}\text { Gas } \\
\text { draina } \\
\text { ge } \\
\text { purity } \\
\mathrm{m}^{3} / \mathrm{mi} \\
\mathrm{n}\end{array}$ & \\
\hline 0 & 0 & 0 & 0 & $\begin{array}{c}1177 . \\
80\end{array}$ & 0.24 & 2.36 & $\begin{array}{c}760.2 \\
0\end{array}$ & 5.69 & 43.26 & 0 \\
\hline 1000 & 52.20 & 96.50 & 50.37 & $\begin{array}{c}1162 . \\
20\end{array}$ & 0.22 & 2.32 & $\begin{array}{c}757.2 \\
0\end{array}$ & 3.43 & 25.97 & 64.03 \\
\hline 2000 & $\begin{array}{c}106.8 \\
0\end{array}$ & 93.67 & $\begin{array}{c}100.0 \\
4\end{array}$ & $\begin{array}{c}1602 . \\
4\end{array}$ & 0.22 & 2.30 & $\begin{array}{c}754.8 \\
0\end{array}$ & 2.76 & 20.83 & 81.22 \\
\hline 3000 & $\begin{array}{c}161.4 \\
0\end{array}$ & 87.17 & $\begin{array}{c}140.6 \\
9\end{array}$ & $\begin{array}{c}1133 . \\
40\end{array}$ & 0.21 & 2.27 & $\begin{array}{c}751.8 \\
0\end{array}$ & 2.31 & 17.37 & 87.75 \\
\hline
\end{tabular}


Table 6 Parameters of simulation results

\begin{tabular}{cccc}
\hline $\begin{array}{c}\text { Negative pressure in } \\
\text { roof roadway/ Pa }\end{array}$ & $\begin{array}{c}\text { Width of possible } \\
\text { SponCom zone in the } \\
\text { air-intake side } / \mathrm{m}\end{array}$ & $\begin{array}{c}\text { Width of possible } \\
\text { SponCom zone in the } \\
\text { central gob/m }\end{array}$ & $\begin{array}{c}\text { Width of possible } \\
\text { SponCom zone in the } \\
\text { air-return side } / \mathrm{m}\end{array}$ \\
\hline 0 & 58 & 69 & 89 \\
-1000 & 60 & 72 & 81 \\
-2000 & 68 & 76 & 73 \\
-3000 & 76 & 80 & 69 \\
\hline
\end{tabular}


Table 7 Parameters of simulation results

\begin{tabular}{cccccccc}
\hline Negative pressure in roof roadway /Pa & 0 & 500 & 1000 & 1500 & 2000 & 2500 & 3000 \\
\hline Gas concentration in tailgate roadway $/ \%$ & 5.69 & 4.05 & 3.43 & 3.05 & 2.76 & 2.52 & 2.31
\end{tabular}


Table 8 The change data of the concentration of ventilation air methane with the change of negative

pressure of the tail roadway

\begin{tabular}{cccccc}
\hline $\begin{array}{c}\text { Air } \\
\text { volume in } \\
\text { tailgate } \\
\begin{array}{c}\text { roadway } \\
/ \mathrm{m}^{3} / \mathrm{min}\end{array}\end{array}$ & $\begin{array}{c}\text { Air } \\
\text { distribution } \\
\text { ratio of the air } \\
\text { return way } \\
\text { and the tail } \\
\text { roadway }\end{array}$ & $\begin{array}{c}\text { Gas } \\
\text { concentration in } \\
\text { air return way/\% }\end{array}$ & $\begin{array}{c}\text { Upper corner gas } \\
\text { concentration } \\
1 \%\end{array}$ & $\begin{array}{c}\text { Gas } \\
\text { concentration in } \\
\text { tailgate roadway } \\
/ \%\end{array}$ & $\begin{array}{c}\text { Gas drainage purity } \\
\text { in tailgate } \\
\text { roadway/m } / \text { min }\end{array}$ \\
\hline 600 & $0.67: 0.33$ & 0.88 & 1.60 & 0.98 & \\
650 & $0.64: 0.36$ & 0.69 & 0.92 & 1.31 & 5.86 \\
700 & $0.61: 0.39$ & 0.51 & 0.62 & 1.53 & 10.54 \\
750 & $0.58: 0.42$ & 0.50 & 0.53 & 1.49 & 11.18 \\
800 & $0.56: 0.44$ & 0.49 & 0.50 & 1.45 & 11.61 \\
900 & $0.50: 0.50$ & 0.49 & 0.49 & 1.34 & 12.04 \\
1000 & $0.44: 0.56$ & 0.48 & 0.48 & 1.25 & 12.47 \\
\hline
\end{tabular}


Table 9 Parameters of simulation results

\begin{tabular}{cccc}
\hline $\begin{array}{c}\text { Airflow in tailgate } \\
\text { roadway } \\
/ \mathrm{m}^{3} / \mathrm{min}\end{array}$ & $\begin{array}{c}\text { Width of possible } \\
\text { SponCom zone in the } \\
\text { air-intake side } / \mathrm{m}\end{array}$ & $\begin{array}{c}\text { Width of possible } \\
\text { SponCom zone in the } \\
\text { central gob/m }\end{array}$ & $\begin{array}{c}\text { Width of possible } \\
\text { SponCom zone in the } \\
\text { air-return side } / \mathrm{m}\end{array}$ \\
\hline 600 & 36 & 44 & 104 \\
700 & 36 & 44 & 105 \\
800 & 36 & 44 & 106 \\
900 & 34 & 41 & 107 \\
1000 & 32 & 40 & 110 \\
1100 & 30 & 39 & 114 \\
\hline
\end{tabular}




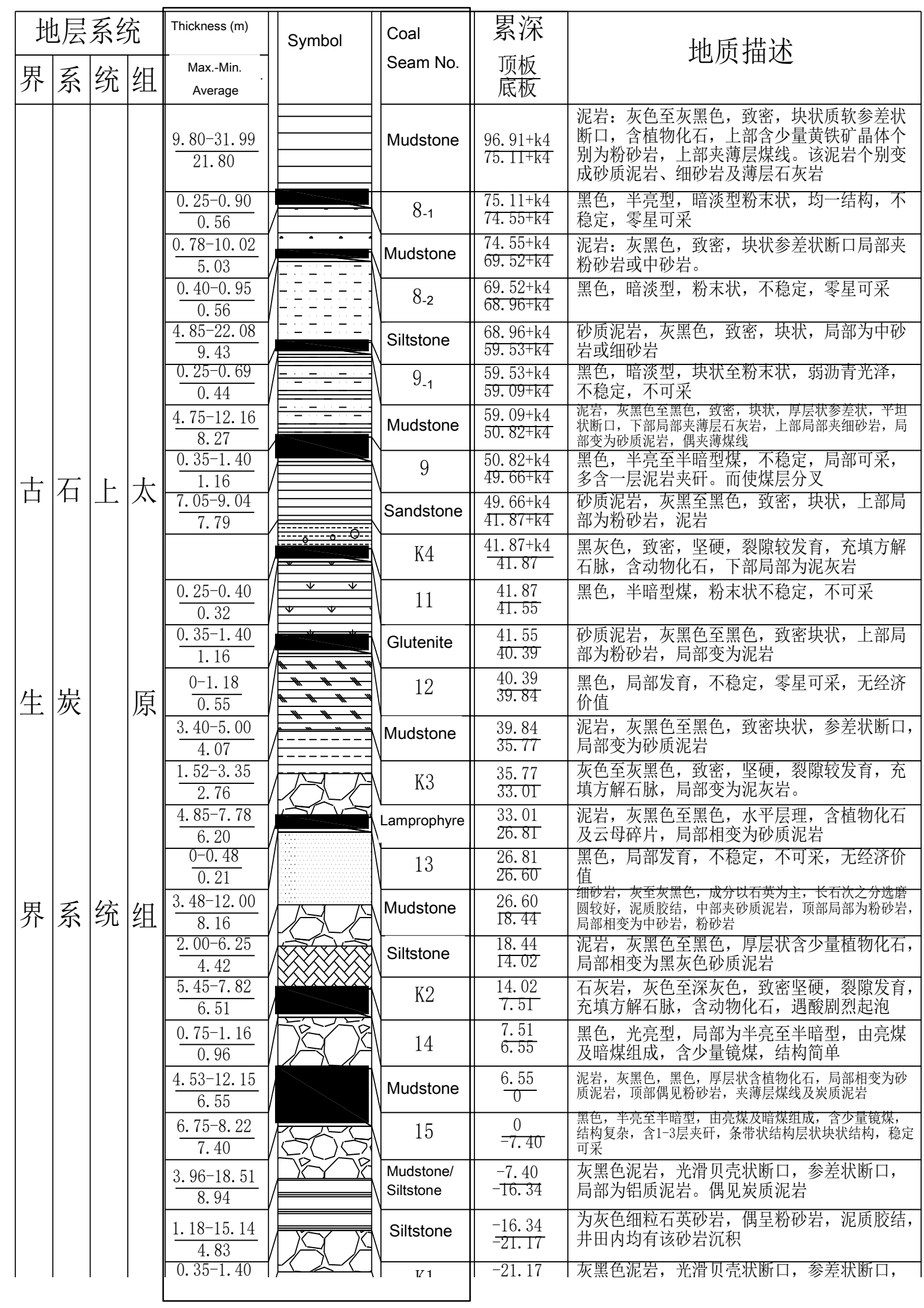

Figure 1(a) coal seams over coal working face 


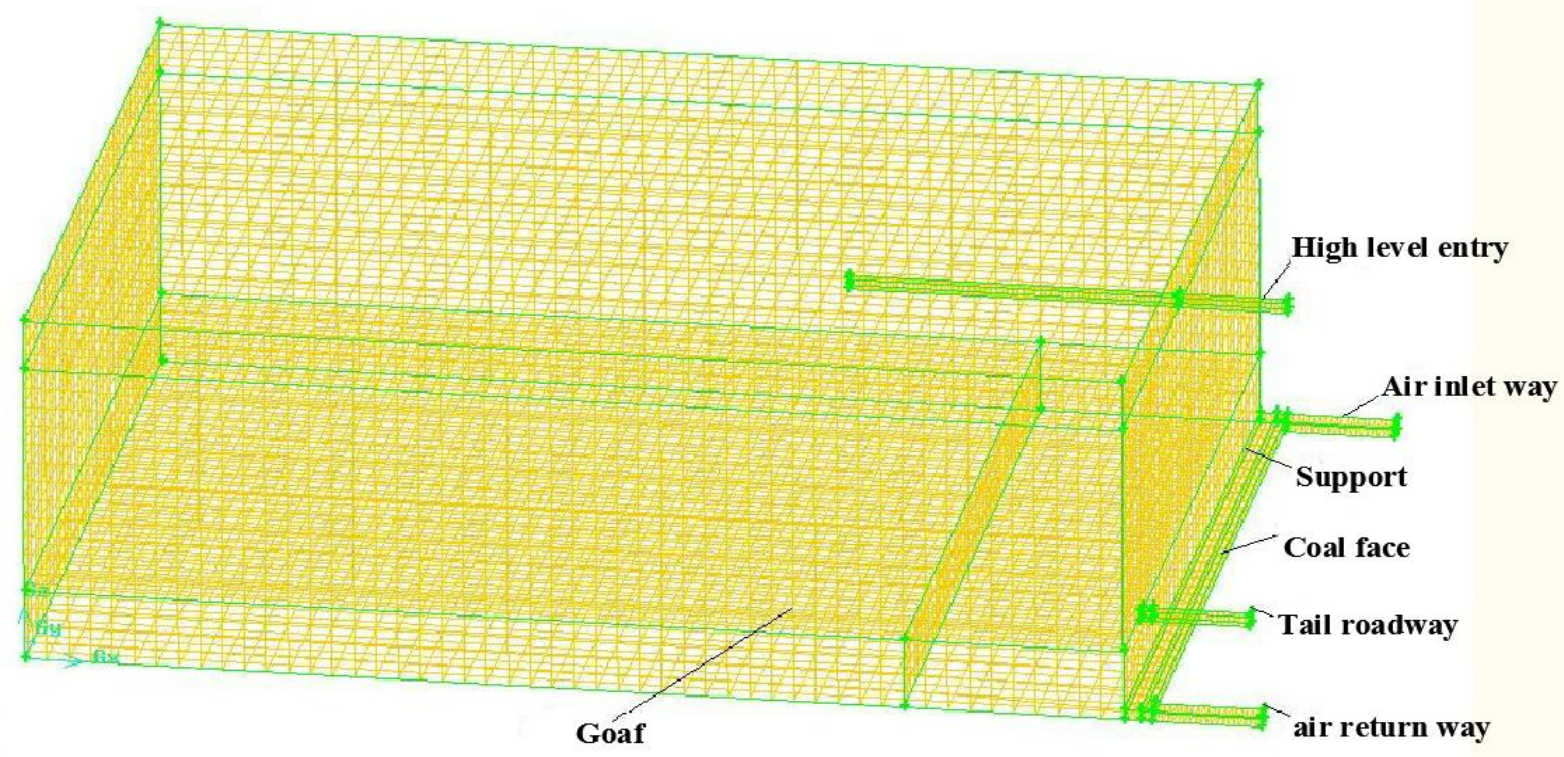

Figure 2 Physical model of the coal face and its meshing 


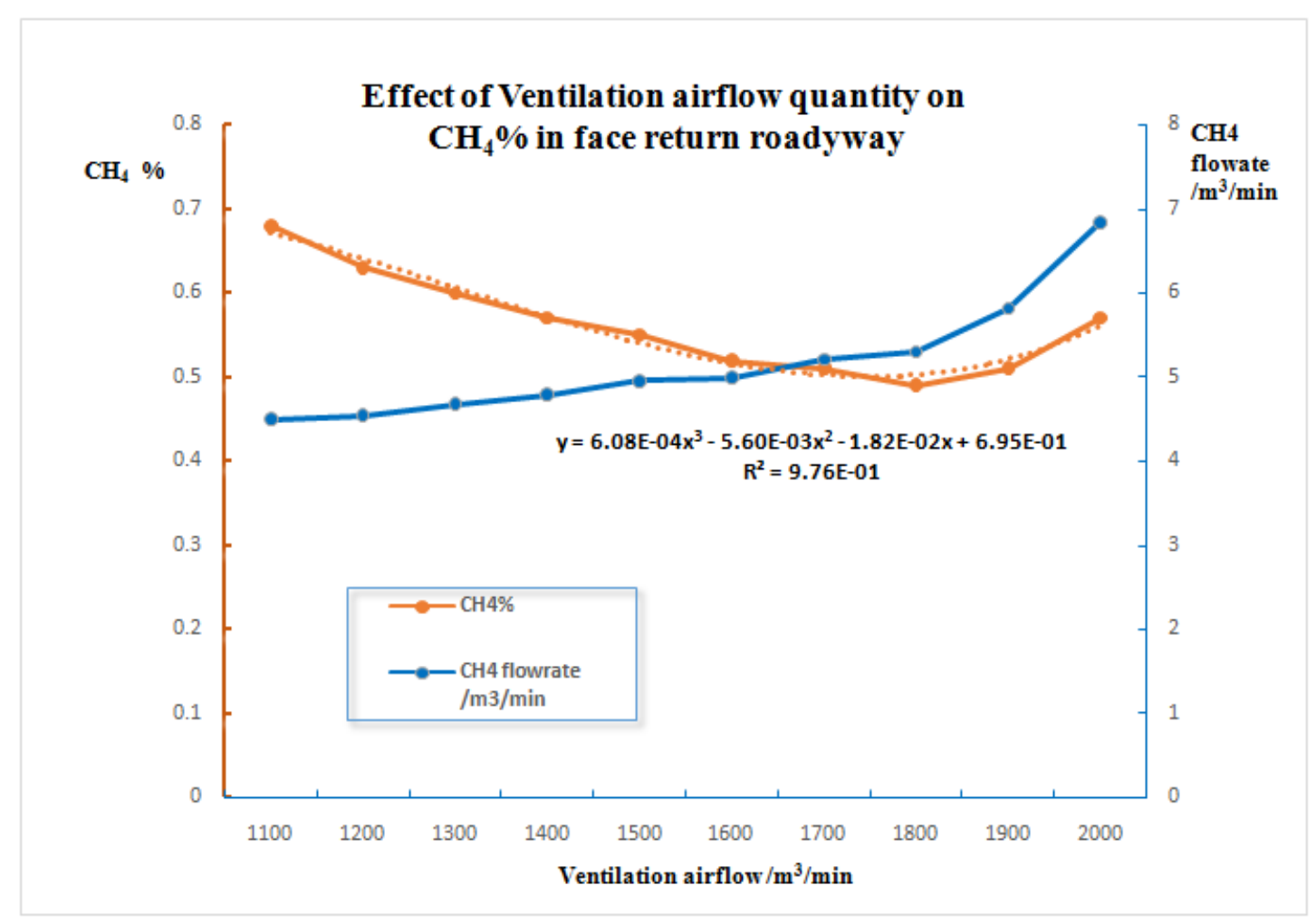

Figure 3 The fitting curve of the variation tendency of gas parameters in the air return roadway 


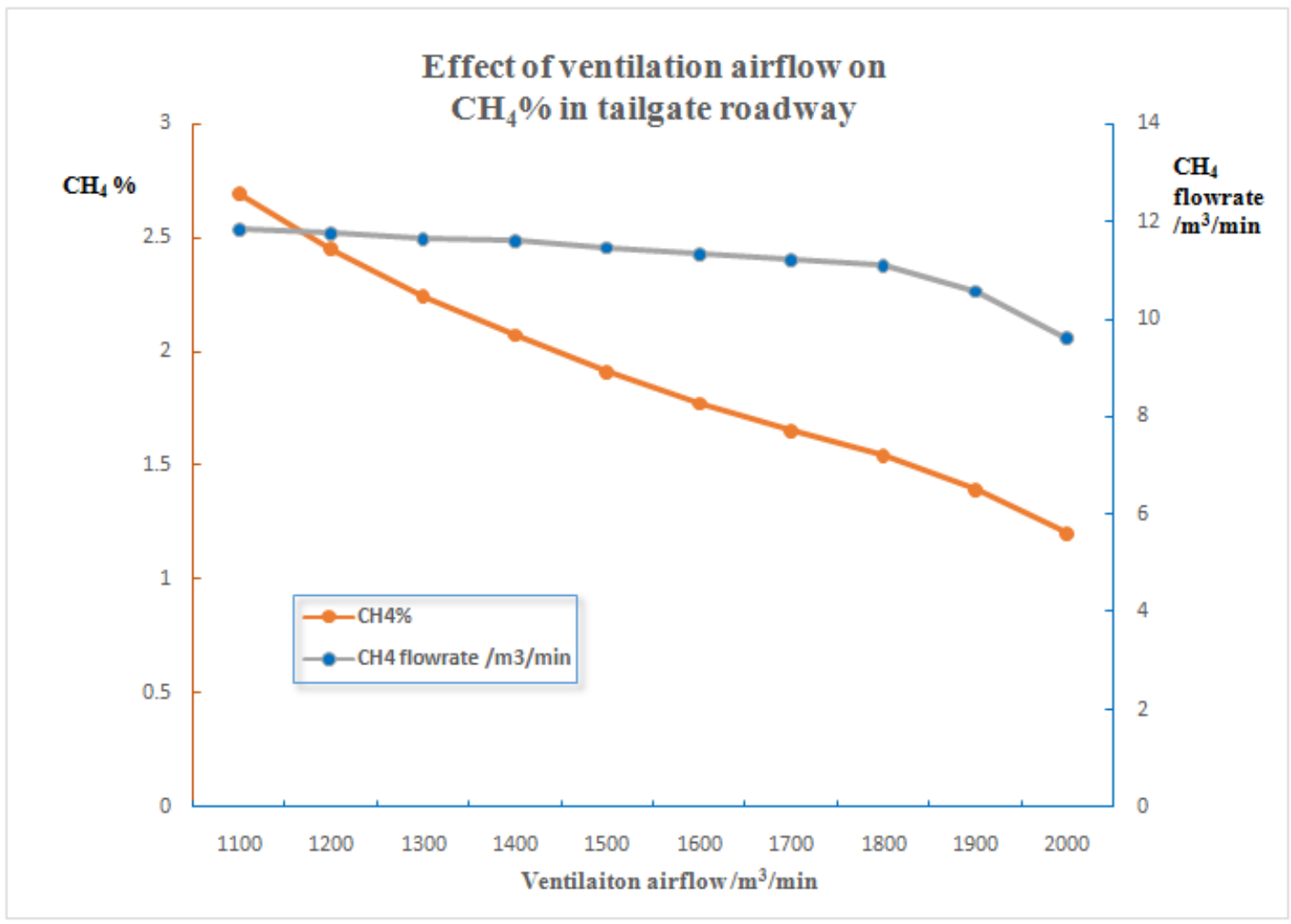

Figure 4 The fitting curve of the variation tendency of gas parameters in the tailgate roadway 


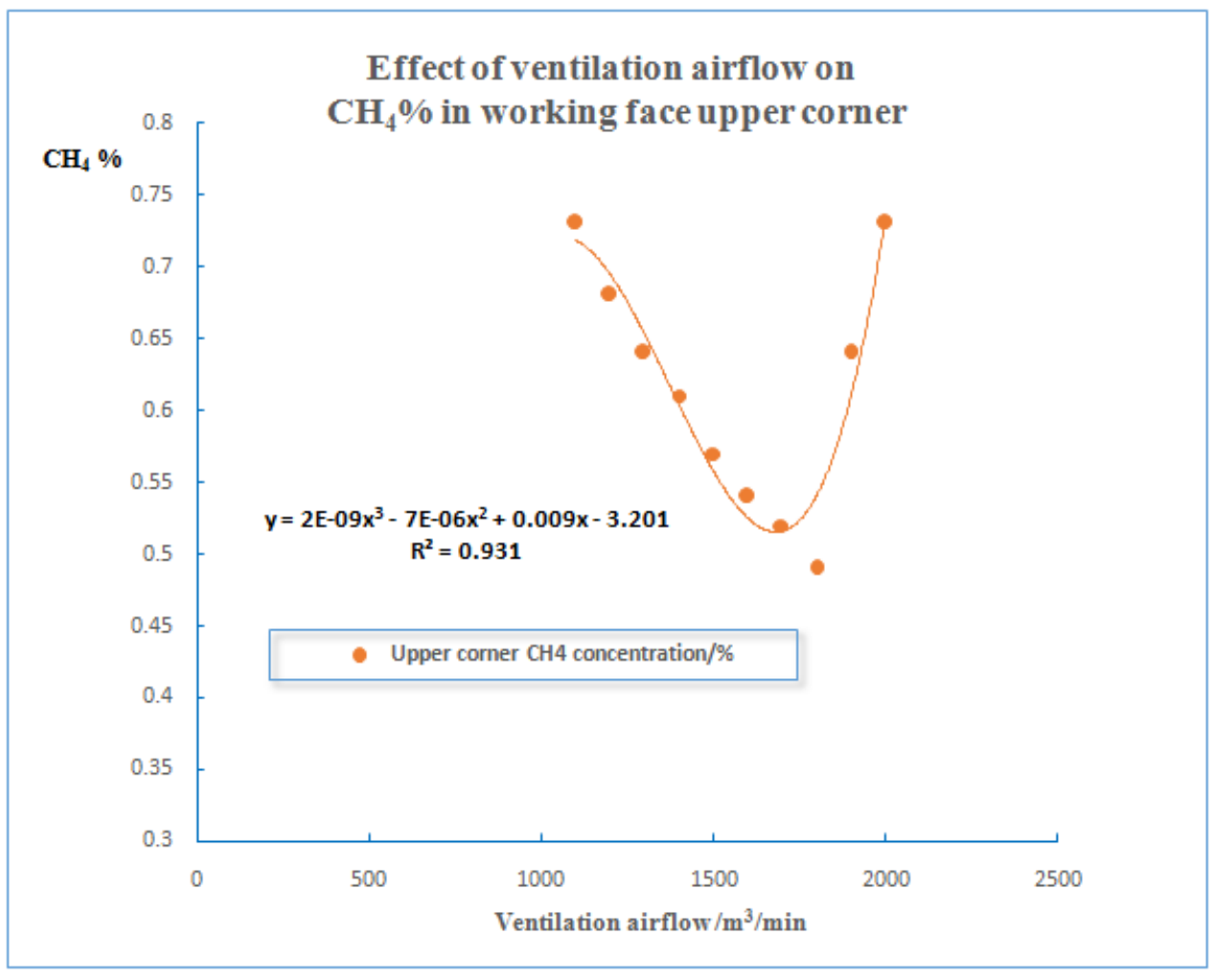

Figure 5 The fitting curve of the variation tendency of the gas parameters in the upper corner 


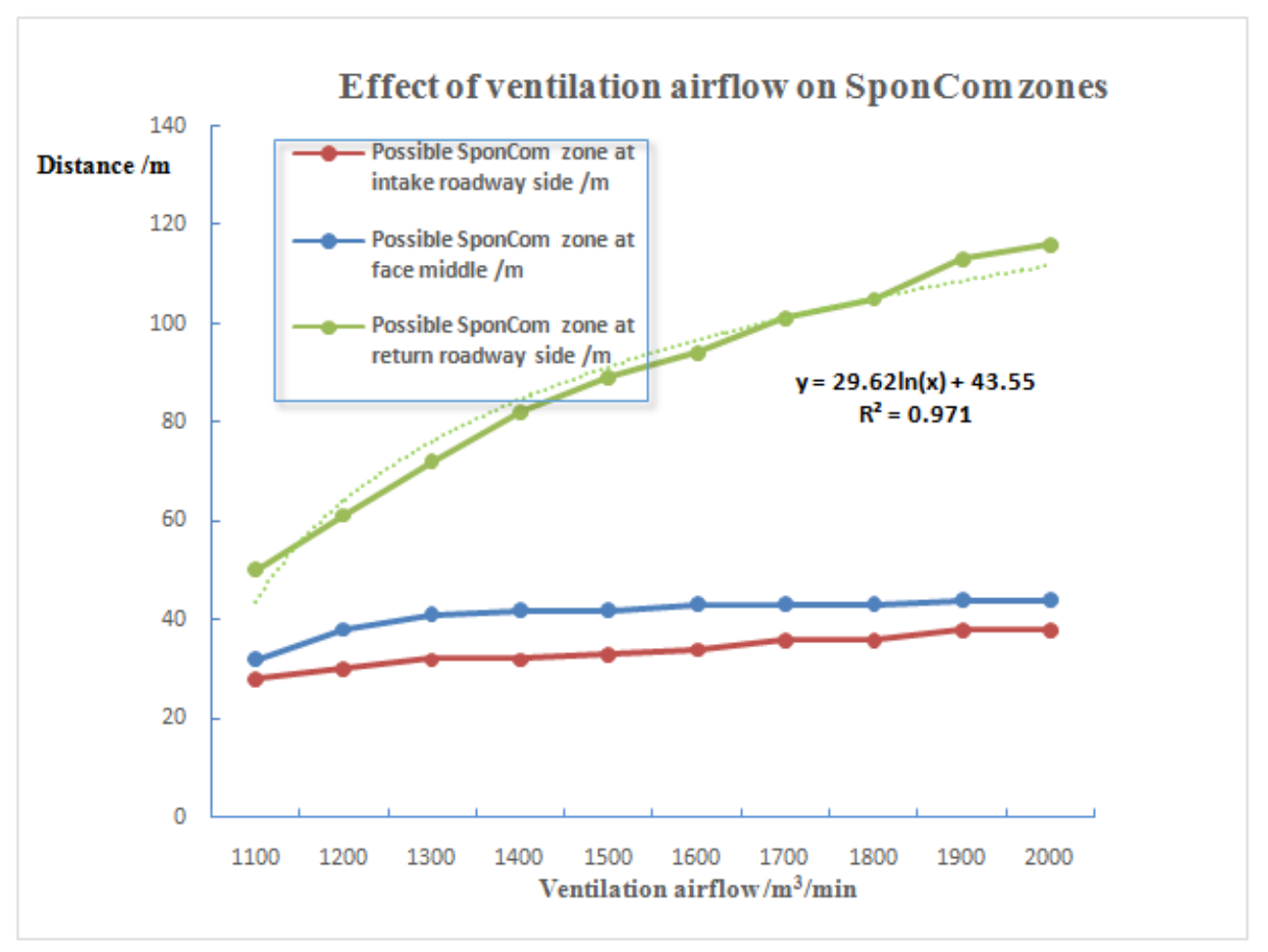

Figure 6 The fitting curve of the range of auto-ignition belts with the change of air supply 


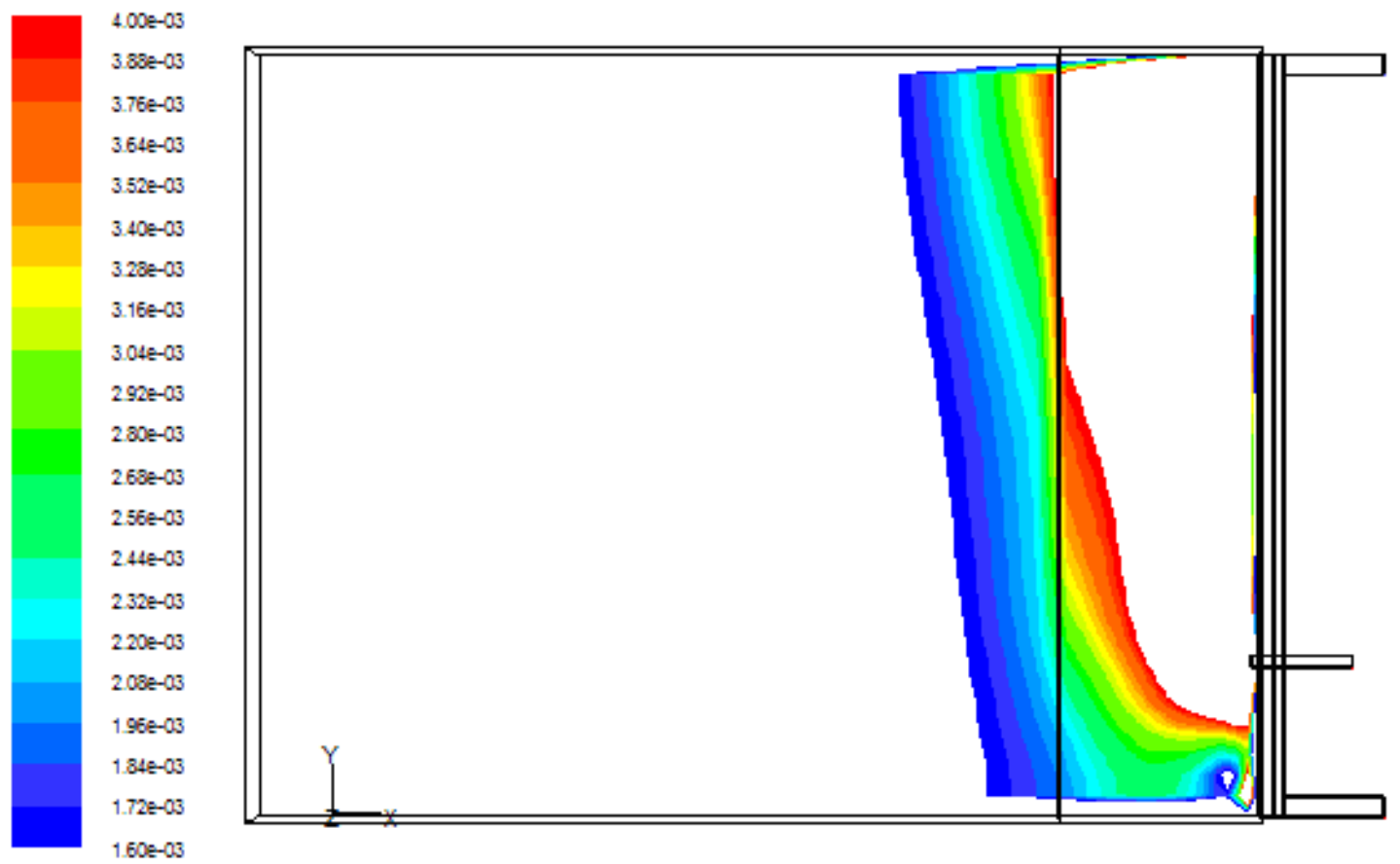

Figure 7 A example of possible SponCom zone when $Q=1300 \mathrm{~m}^{3} / \mathrm{min}$ 


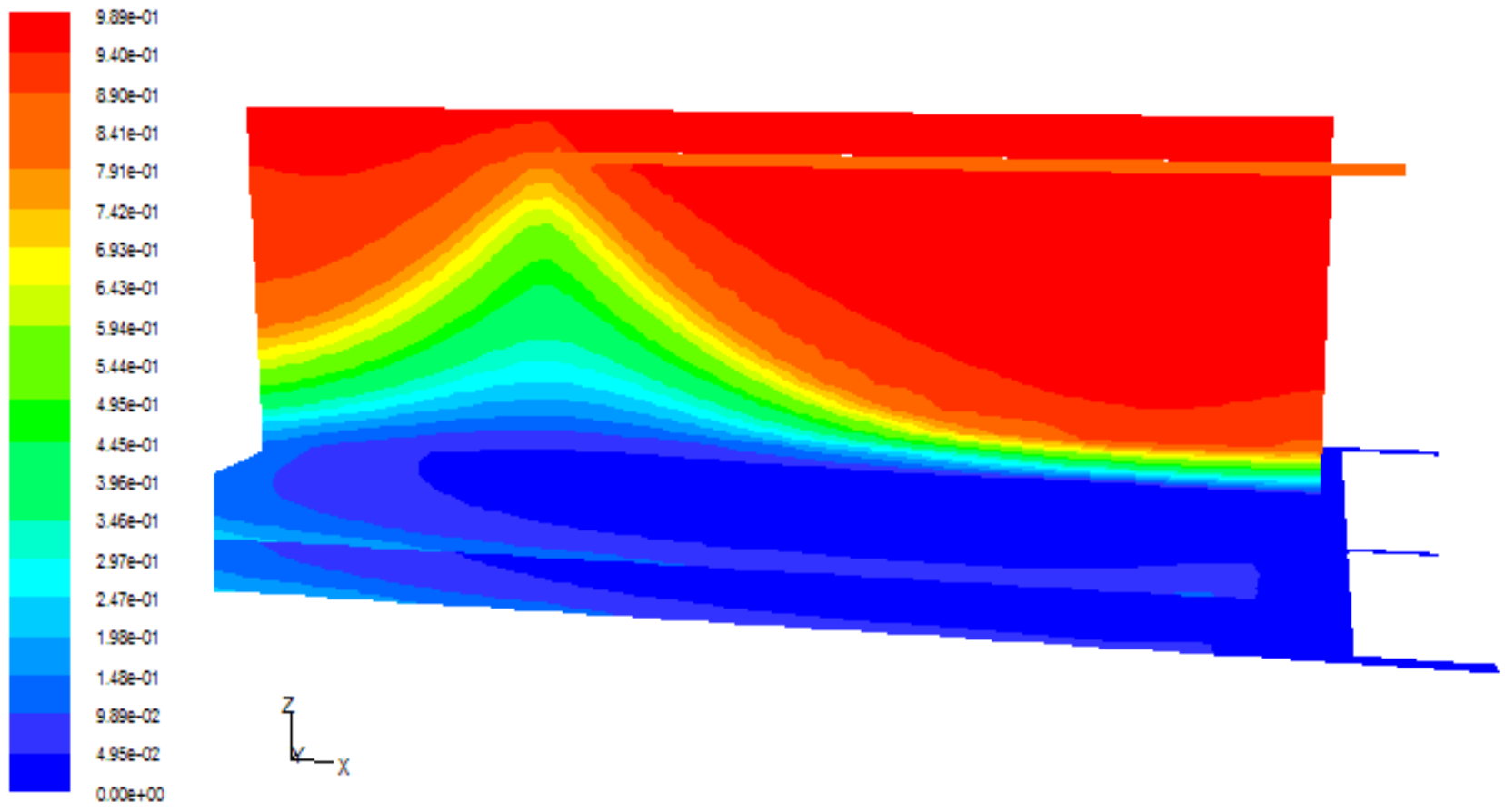

Figure 8 Cloud chart of the gas concentration 


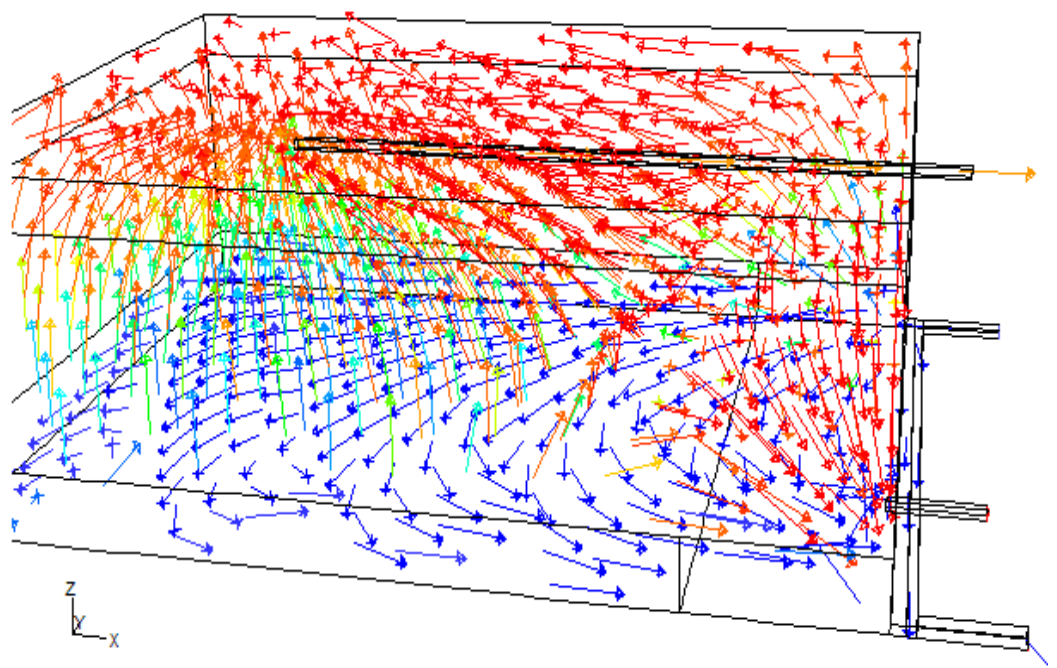

Figure 9 The vector diagram of wind current in the gob 


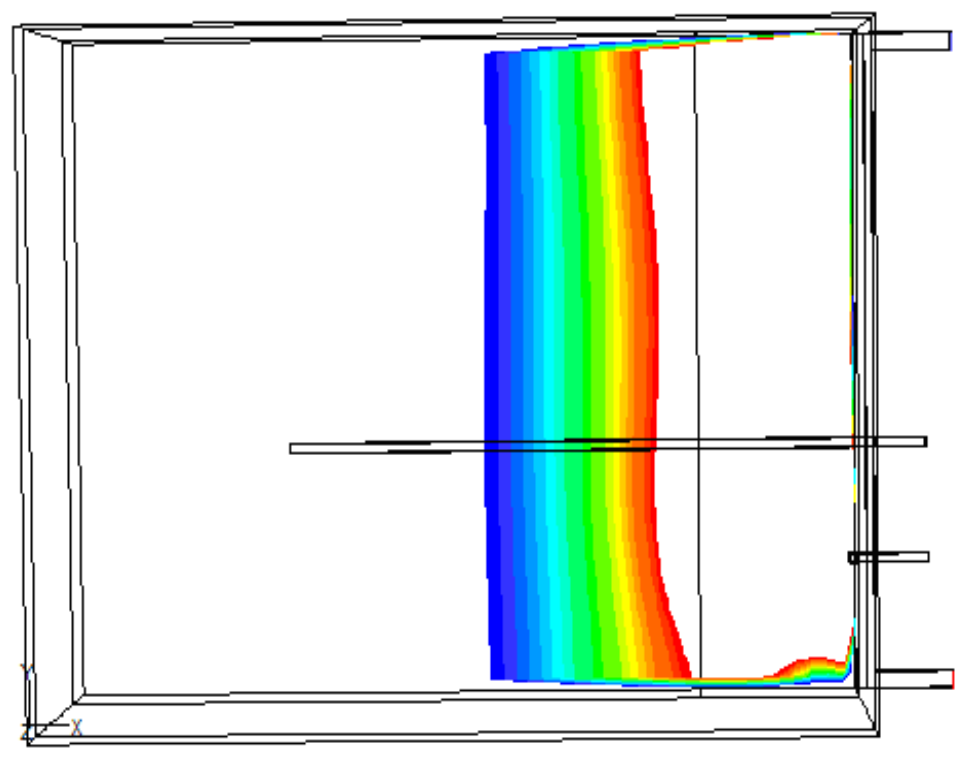

Figure 10 Possible sponcom zones (Pressure is 0Pa) 


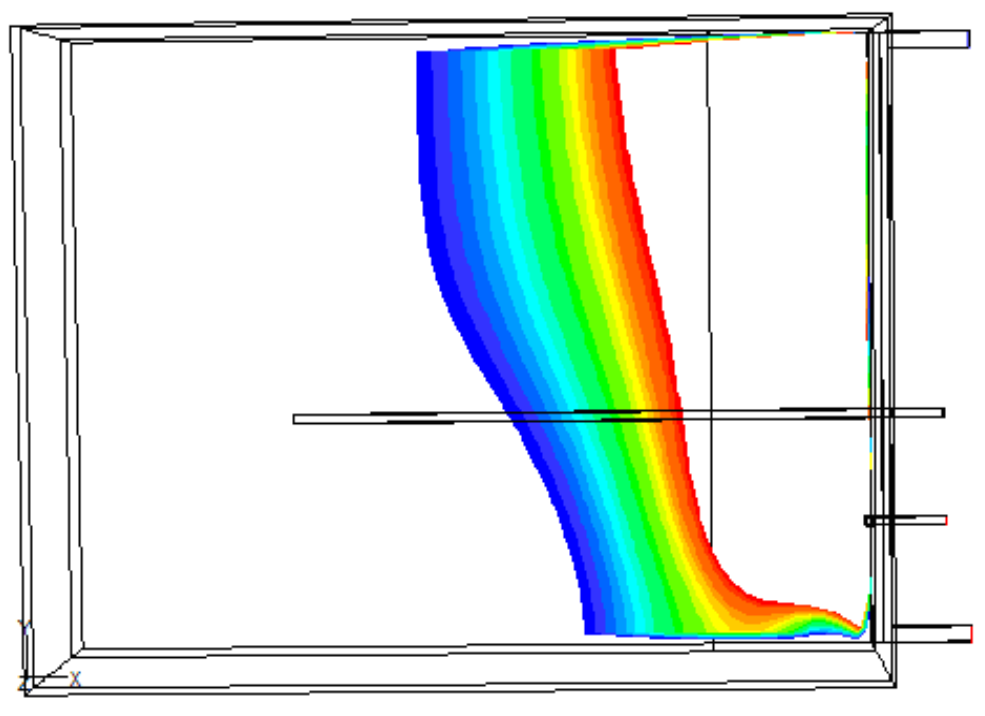

Figure 11 Possible sponcom zone ( Pressure is 3000Pa) 


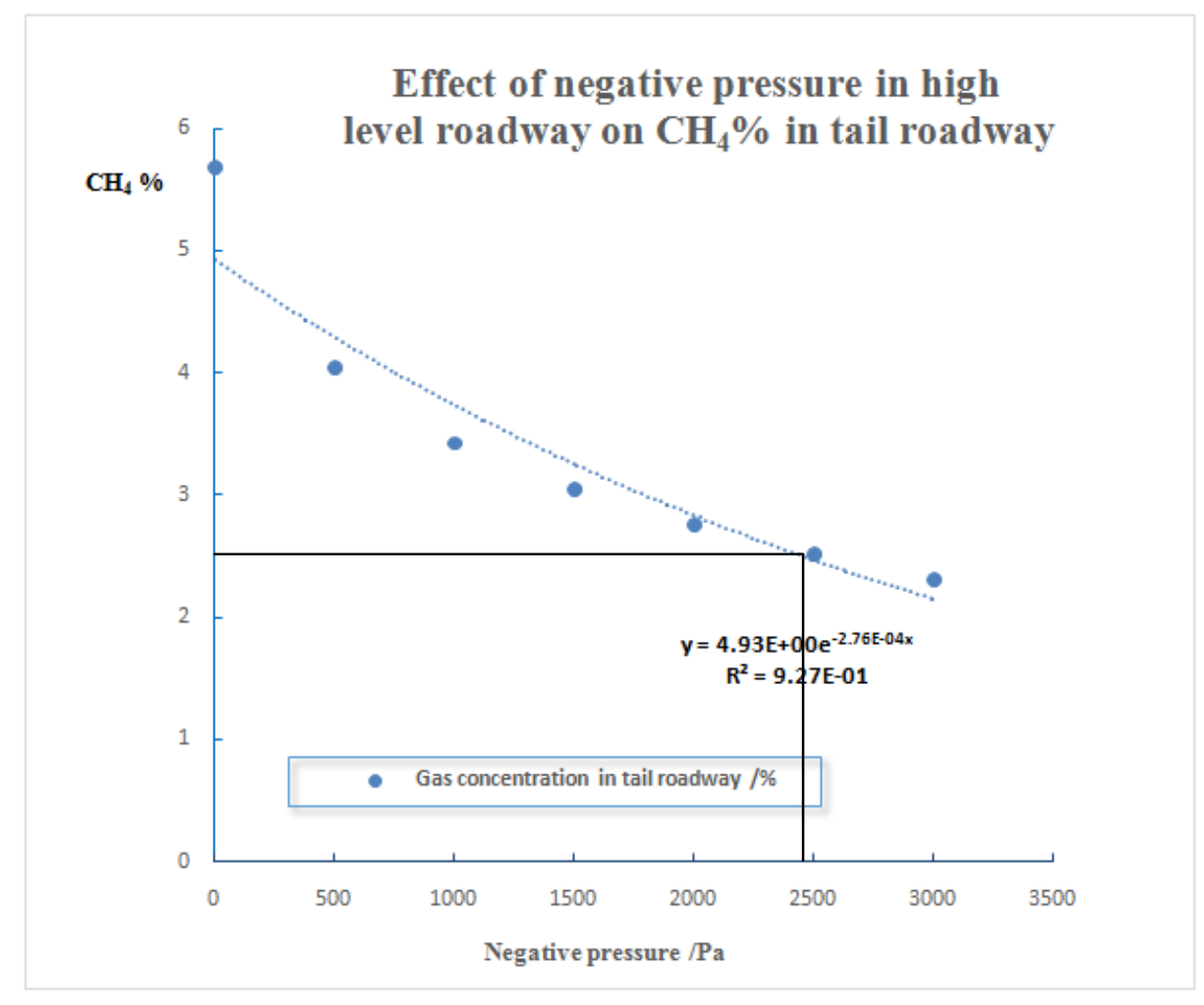

Figure 12 Effect of high level negative pressure to the $\mathrm{CH}_{4} \%$ in tail roadway 

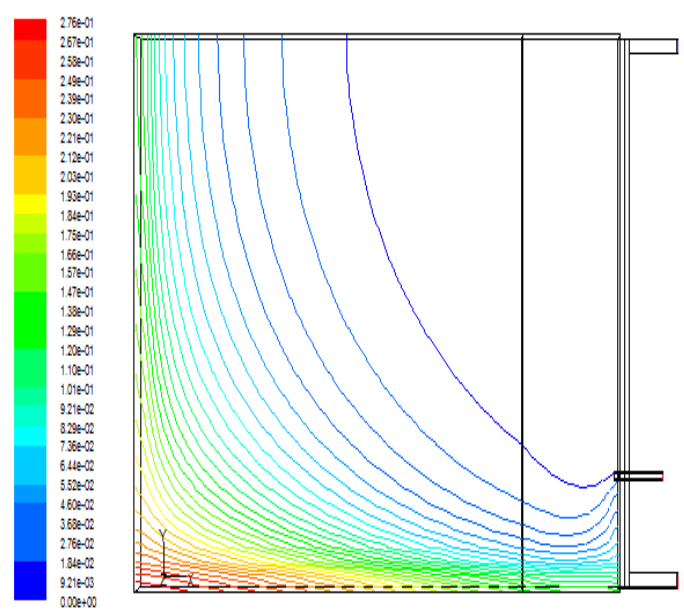

Airflow rate in tailgate is $600 \mathrm{~m} 3 / \mathrm{min}$
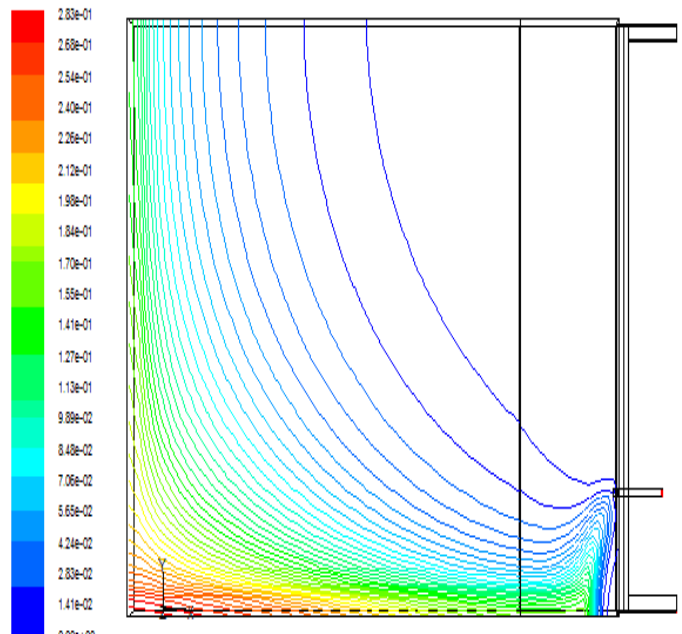

Airflow rate in tailgate is $800 \mathrm{~m} 3 / \mathrm{min}$

Airflow rate in tailgate is $900 \mathrm{~m} 3 / \mathrm{min}$
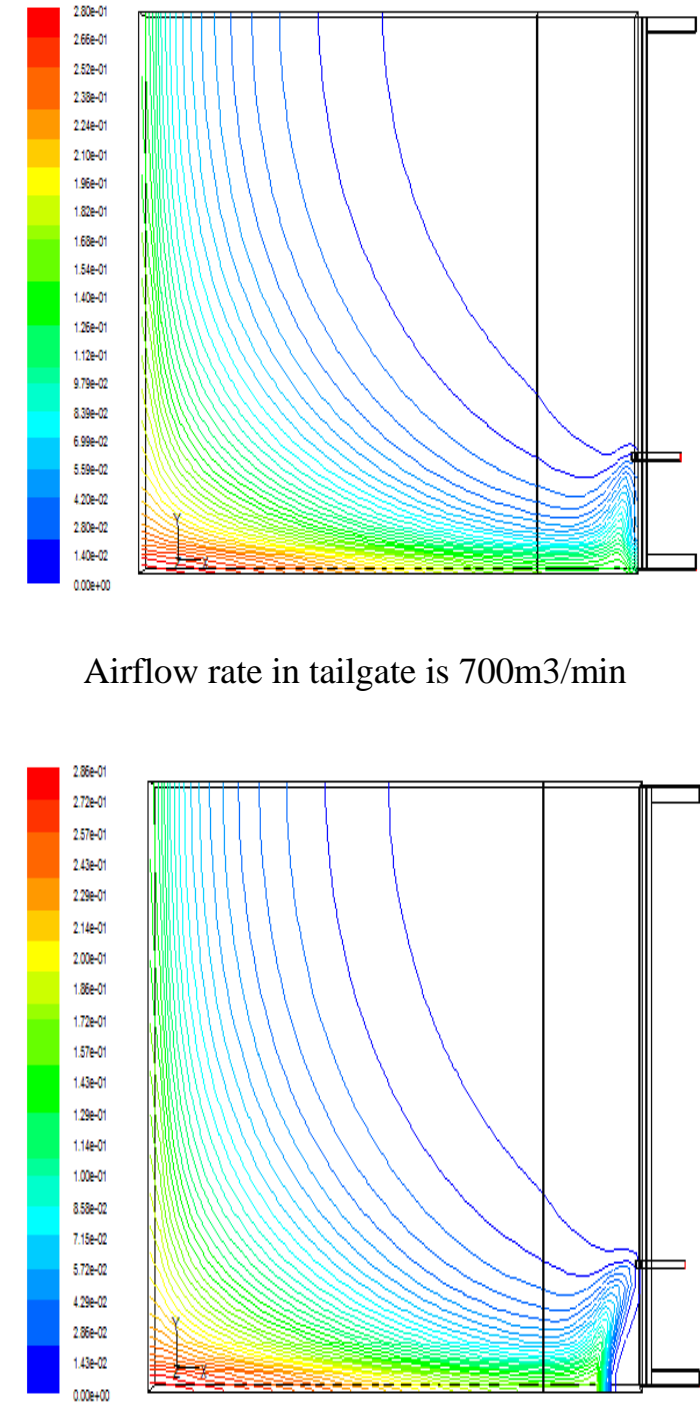

Airflow rate in tailgate is $700 \mathrm{~m} 3 / \mathrm{min}$

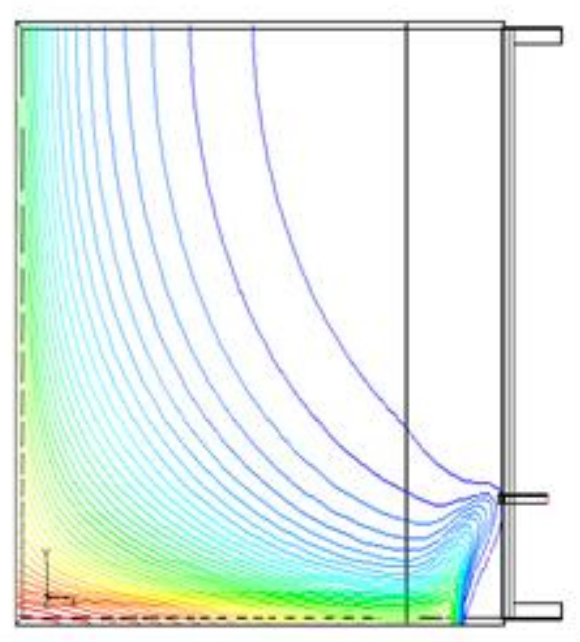

Airflow rate in tailgate is $1000 \mathrm{~m} 3 / \mathrm{min}$

Figure 13 The change trend of gas concentration at coal mine 


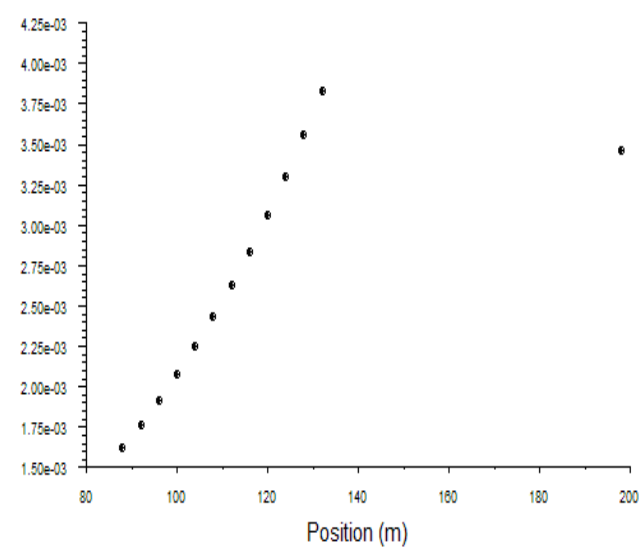

Airflow rate in tailgate is $600 \mathrm{~m} 3 / \mathrm{min}$

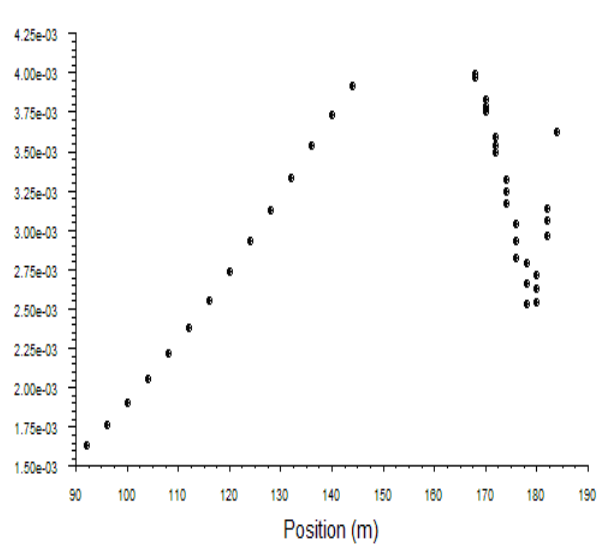

Airflow rate in tailgate is $1100 \mathrm{~m} 3 / \mathrm{min}$

Figure 14 Scatter diagram of the possible auto-ignition scope of air return side 